\title{
Hybrid Inorganic-organic Composites of Layered Double Hydroxides Intercalated with Organic Acid Anions for the Uptake of Hazardous Substances from Aqueous Solution
}

\author{
Tomohito Kameda and Toshiaki Yoshioka \\ Graduate School of Environmental Studies, Tohoku University \\ Japan
}

\section{Introduction}

Layered double hydroxide $(\mathrm{LDH})$ is an inorganic compound with a layered structure and exhibits anion-exchange properties. Its basic chemical composition is $\left[\mathrm{M}^{2+}{ }_{1-x} \mathrm{M}^{3+}{ }_{\mathrm{x}}(\mathrm{OH})_{2}\right]\left(\mathrm{A}^{\mathrm{n}-}\right.$ )$_{x / n} \bullet \mathrm{mH}_{2} \mathrm{O}$, where $\mathrm{x}$ is the $\mathrm{M}^{3+} /\left(\mathrm{M}^{2+}+\mathrm{M}^{3+}\right)$ molar ratio and $\mathrm{A}^{\mathrm{n}-}$ indicates an anion with a valency of $n$ (Ingram and Taylor, 1967; Allmann, 1968; Taylor, 1973). Its crystal structure consists of positively charged brucite-like octahedral hydroxide layers containing $\mathrm{M}^{3+}$ at $\mathrm{M}^{2+}$ sites, which are electrically neutralized by the interlayer anions, and water molecules in the hydration shell of the intercalated anions occupying the remaining interlayer space. Among various types of $\mathrm{LDH}$ composed of different compositions of $\mathrm{M}^{2+}$ and $\mathrm{M}^{3+}, \mathrm{Mg}-\mathrm{Al} \mathrm{LDH}$ has been used practically as an antacid and a flame retardant (Cavani et al., 1991). $\mathrm{Mg}-\mathrm{Al}$ $\mathrm{LDH}$ intercalated with $\mathrm{CO}_{3}{ }^{2-}\left(\mathrm{CO}_{3} \bullet \mathrm{Mg}-\mathrm{Al} \mathrm{LDH}\right)$ can be transformed into $\mathrm{Mg}-\mathrm{Al}$ oxide by calcination at $450-800^{\circ} \mathrm{C}$ according to the following reaction:

$$
\mathrm{Mg}_{1-x} \mathrm{Al}_{\mathrm{x}}(\mathrm{OH})_{2}\left(\mathrm{CO}_{3}\right)_{x / 2} \rightarrow \mathrm{Mg}_{1-x} \mathrm{Al}_{\mathrm{x}} \mathrm{O}_{1+x / 2}+\mathrm{x} / 2 \mathrm{CO}_{2}+\mathrm{H}_{2} \mathrm{O}
$$

$\mathrm{Mg}-\mathrm{Al}$ oxide can rehydrate and combine with anions to reconstruct the $\mathrm{LDH}$ structure in the following manner:

$$
\mathrm{Mg}_{1-x} \mathrm{Al}_{\mathrm{x}} \mathrm{O}_{1+\mathrm{x} / 2}+\mathrm{x} / \mathrm{n} \mathrm{\textrm {A } ^ { - }}+(1+\mathrm{x} / 2) \mathrm{H}_{2} \mathrm{O} \rightarrow \mathrm{Mg}_{1-\mathrm{x}} \mathrm{Al}_{\mathrm{x}}(\mathrm{OH})_{2} \mathrm{~A}_{\mathrm{x} / \mathrm{n}}+\mathrm{xOH} \mathrm{H}^{-}
$$

$\mathrm{LDH}$ can intercalate various anions. Recently, modification of $\mathrm{LDH}$ with organic anions has received considerable attention, as summarized in a review by Newman and Jones (1998), with possible applications in catalysis, photochemistry, and electrochemistry.

We carried out a series of studies to develop hybrid inorganic-organic composite materials by intercalation of organic anions having functional groups in their structures into the interlayer of LDH. Due to the action of the functional groups of the organic anions, the composite materials are expected to selectively take up and collect both inorganic and organic contaminants present at low concentrations in aqueous solutions.

The aims and concerns presented in this chapter are the preparation of organically modified $\mathrm{LDH}$ by intercalation of organic anions into the interlayer of $\mathrm{LDH}$ and the uptake of heavy metal ions and nonionic organic compounds by the organically modified LDH. 


\section{Uptake of heavy metal ions by organically modified LDH}

Due to slow reactivity and inefficiency, the application of chelate resins in the treatment of wastewater with a high concentration of heavy metal ions is difficult. Generally, a two-step process is considered acceptable for wastewater treatment. First, the heavy metal ions are removed from the wastewater by a chemical precipitation technique, and then the remaining heavy metal ions are treated using chelate resins. A one-step method capable of achieving highly effective wastewater treatment is desired. A one-step method is thought to be possible by applying a scavenger that can function as chelate resins and can rapidly remove heavy metal ions from wastewater, decreasing the heavy metal ion concentration to the level of the effluent standards in Japan. The aim of the present study was to develop an organic-inorganic composite material to scavenge heavy metal ions from wastewaters. Chelate resin contains functional groups such as aminocarboxylate and polyamine that form chelate bonds with heavy metal ions. Therefore, we developed a scavenger by incorporating an organic acid anion having functional groups in its structure into the inorganic compound. Aminocarboxylates such as an ethylenediaminetetraacetate (EDTA) anion were examined as functional groups. Then, $\mathrm{LDH}$ was examined as the inorganic compound.

Several studies have examined the use of $\mathrm{LDH}$ and calcined LDH for the preservation of aqueous environments. $\mathrm{LDH}$ and calcined $\mathrm{LDH}$ can take up oxometalates such as $\mathrm{Cr}_{2} \mathrm{O}_{7}{ }^{2-}$, $\mathrm{SeO}_{3}{ }^{2-}, \mathrm{SeO}_{4}{ }^{2-}, \mathrm{AsO}_{3}{ }^{3-}, \mathrm{AsO}_{4}{ }^{3-}, \mathrm{TcO}_{4}{ }^{-}$, and $\mathrm{ReO}_{4}{ }^{-}$from aqueous solution (Dousova et al., 2003; Gillman, 2006; Goswamee et al., 1998; Kang et al., 1996; Lazaridis and Asouhidou, 2003; Rhee et al., 1997; Tsuji et al., 1999; Wang et al., 2009; Yang et al., 2005; You et al., 2001a; You et al., 2001b). Goh et al. (2008) reviewed the application of LDH for removal of oxometalates. LDH, when acting as a hydroxide, has also acted as a precipitation reagent for heavy metal ions such as $\mathrm{Cu}^{2+}, \mathrm{Pb}^{2+}$, and $\mathrm{Zn}^{2+}$ in wastewater via hydroxide formation (Fujii et al., 1992). However, heavy metal cations cannot be intercalated in the interlayer of LDH. In order to take up heavy metal cations using inorganic materials from aqueous solution, cationic clay such as montmorillonite is typically used due to its cation-exchange properties. On the other hand, EDTA anions can be intercalated in the interlayer of LDH (Narita et al., 1995). Similarly, stable anionic chelates formed between heavy metal ions and aminocarboxylates such as EDTA can be also intercalated in the interlayer of LDH. For example, the intercalations of $\mathrm{Ni}(\mathrm{EDTA})^{2-}, \mathrm{Co}(\mathrm{EDTA})^{2-}, \mathrm{Cu}(\mathrm{EDTA})^{2-}, \mathrm{Zn}(\mathrm{EDTA})^{2-}$, and Cd(EDTA) ${ }^{2-}$ have been examined (Sato et al., 1990; Narita et al., 1995; Tsyganok et al., 2001a; Tsyganok et al., 2001b; Lukashin et al., 2003; Tsyganok and Sayari, 2006). Accordingly, we have developed a scavenger by intercalating an EDTA anion in the interlayer of LDH and applied the scavenger to decrease the concentrations of heavy metal ions in aqueous solutions for the first time. In order for the scavenger to take up heavy metal ions from an aqueous solution, the EDTA anion should function as a chelating agent in the interlayer of LDH. In the following section, we discuss our work along with related studies.

\subsection{LDH intercalated with EDTA}

The EDTA $\bullet \mathrm{Mg}-\mathrm{Al} \mathrm{LDH}$, which had an EDTA anion intercalated in the interlayer of $\mathrm{Mg}-\mathrm{Al}$ $\mathrm{LDH}$, was synthesized by adding a solution of $\mathrm{Mg}\left(\mathrm{NO}_{3}\right)_{2}$ and $\mathrm{Al}\left(\mathrm{NO}_{3}\right)_{3}$ to a solution of $\mathrm{NaOH}$ and EDTA-2Na (disodium dihydrogen EDTA dihydrate) according to the coprecipitation reaction expressed by Eq. (3) and by mixing at $30^{\circ} \mathrm{C}$ for $1 \mathrm{~h}$ (Kameda et al., 2005a).

$$
0.75 \mathrm{Mg}^{2+}+0.25 \mathrm{Al}^{3+}+2 \mathrm{OH}^{-}+0.0625 \mathrm{EDTA}^{4-} \rightarrow \mathrm{Mg}_{0.75} \mathrm{Al}_{0.25}(\mathrm{OH})_{2}(\mathrm{EDTA})_{0.0625}
$$


Since the EDTA $\bullet \mathrm{Mg}-\mathrm{Al} \mathrm{LDH}$ was prepared in the $\mathrm{pH}$ range where EDTA anions exist stably as tetravalent anions by setting the $\mathrm{NaOH}$ concentration in the EDTA solution to 1.2 times the stoichiometric quantity defined by Eq. (3), the EDTA $\bullet \mathrm{Mg}-\mathrm{Al} \mathrm{LDH}$ was considered to be a $\mathrm{Mg}-\mathrm{Al} \mathrm{LDH}$ having EDTA4- in the interlayer.

EDTA $\bullet \mathrm{Mg}-\mathrm{Al} \mathrm{LDH}$ was added to $1.0 \mathrm{mM} \mathrm{MCl}_{2}(\mathrm{M}=\mathrm{Cu}, \mathrm{Cd})$ solution or a 1:1 mixed chloride solution of $\mathrm{Cu}^{2+}$ and $\mathrm{Cd}^{2+}$, and then the resultant suspension was kept standing at $20{ }^{\circ} \mathrm{C}$ under mild agitation for $60 \mathrm{~min}$ (Kameda et al., 2005a). The solution $\mathrm{pH}$ was adjusted to 5.0 by addition of $0.1 \mathrm{M}$ hydrochloric acid, and $\mathrm{Cu}^{2+}$ and $\mathrm{Cd}^{2+}$ did not precipitate as their hydroxides. In this case, the molar ratios of EDTA4- in the EDTA $\bullet \mathrm{Mg}-\mathrm{Al} \mathrm{LDH}$ added to $\mathrm{M}^{2+}$ in the $\mathrm{MCl}_{2}$ solution were set at 1.0-2.0 (EDTA4- $\left./ \mathrm{M}^{2+}=1.0-2.0\right)$. For the $\mathrm{Cu}-\mathrm{Cd}$ mixed chloride solution, the EDTA4- $/\left(\mathrm{Cu}^{2+}+\mathrm{Cd}^{2+}\right)$ molar ratio was set at 0.5 . The capacity of $\mathrm{CO}_{3} \bullet \mathrm{Mg}-\mathrm{Al} \mathrm{LDH}$, the interlayer of which was not chemically modified, was also examined to estimate the function of EDTA 4 - in the interlayer of EDTA $\bullet \mathrm{Mg}-\mathrm{Al} \mathrm{LDH}$. Figure 1 shows the variation in the concentration of $\mathrm{Cu}^{2+}$ with time during the stirring of EDTA $\bullet \mathrm{Mg}-\mathrm{Al}$ $\mathrm{LDH}$ or $\mathrm{CO}_{3} \bullet \mathrm{Mg}-\mathrm{Al} \mathrm{LDH}$ in the $\mathrm{CuCl}_{2}$ solution. In this case, the molar ratio of EDTA ${ }^{4-}$ in the EDTA $\bullet \mathrm{Mg}-\mathrm{Al} \mathrm{LDH}$ added to $\mathrm{Cu}^{2+}$ in the $\mathrm{CuCl}_{2}$ solution was set at $1.0\left(\mathrm{EDTA}^{4-} / \mathrm{Cu}^{2+}=\right.$ 1.0). The amount of $\mathrm{CO}_{3} \bullet \mathrm{Mg}-\mathrm{Al} \mathrm{LDH}$ added was equal to that of EDTA $\bullet \mathrm{Mg}-\mathrm{Al} \mathrm{LDH}$.

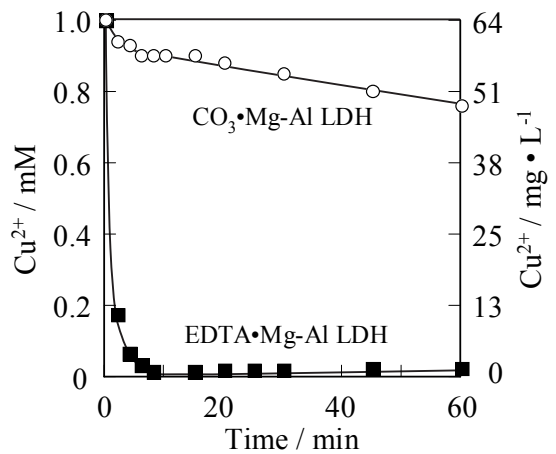

Fig. 1. Variation in the concentration of $\mathrm{Cu}^{2+}$ with time during the stirring of EDTA $\bullet \mathrm{Mg}-\mathrm{Al}$ $\mathrm{LDH}$ or $\mathrm{CO}_{3} \bullet \mathrm{Mg}-\mathrm{Al} \mathrm{LDH}$ in the $\mathrm{CuCl}_{2}$ solution.

For EDTA $\bullet \mathrm{Mg}-\mathrm{Al} \mathrm{LDH}$, the concentration of $\mathrm{Cu}^{2+}$ decreased very rapidly to $0.02 \mathrm{mM}(1$ $\mathrm{mg} / \mathrm{L})$ in $10 \mathrm{~min}$. The uptake of $\mathrm{Cu}^{2+}$ was $20 \mathrm{mg}-\mathrm{Cu}^{2+} / \mathrm{g}$-EDTA $\bullet \mathrm{Mg}-\mathrm{Al} \mathrm{LDH}$. On the other hand, for $\mathrm{CO}_{3} \bullet \mathrm{Mg}-\mathrm{Al} \mathrm{LDH}$, the concentration decreased in a substantially slower manner, to $0.9 \mathrm{mM}(57 \mathrm{mg} / \mathrm{L})$ in $10 \mathrm{~min}\left(2 \mathrm{mg}-\mathrm{Cu}^{2+} / \mathrm{g}-\mathrm{CO}_{3} \cdot \mathrm{Mg}-\mathrm{Al} \mathrm{LDH}\right)$. This difference in the uptake of $\mathrm{Cu}^{2+}$ was attributed to the function of EDTA4- in the interlayer of EDTA $\bullet \mathrm{Mg}-\mathrm{Al}$ LDH. In particular, the $\mathrm{Cu}(\mathrm{EDTA})^{2-}$ complex is thought to form in the interlayer of EDTA $\bullet \mathrm{Mg}-\mathrm{Al} \mathrm{LDH}$. Along with formation of the chelate complexes, $\mathrm{Cl}^{-}$is presumed to intercalate in the interlayer of EDTA $\bullet \mathrm{Mg}-\mathrm{Al} \mathrm{LDH}$ to compensate for the change in negative charge resulting from the change in anionic species from EDTA4- to $\mathrm{Cu}(\mathrm{EDTA})^{2-}$ in the interlayer. On the other hand, a slight decrease in the concentration of $\mathrm{Cu}^{2+}$ was observed for $\mathrm{CO}_{3} \bullet \mathrm{Mg}-\mathrm{Al} \mathrm{LDH}$ (Fig. 1). In this experiment, $0.1 \mathrm{M} \mathrm{HCl}$ was added to the solution to maintain the $\mathrm{pH}$ at 5.0. Due to the decrease in the local $\mathrm{pH}$ by the addition of $\mathrm{HCl}, \mathrm{Mg}^{2+}$ and $\mathrm{Al}^{3+}$ dissolved from $\mathrm{CO}_{3} \bullet \mathrm{Mg}-\mathrm{Al} \mathrm{LDH} . \mathrm{Mg}^{2+}$ was observed to be dissolved from the 
$\mathrm{CO}_{3} \bullet \mathrm{Mg}-\mathrm{Al} \mathrm{LDH}$. On the contrary, the concentration of $\mathrm{Al}^{3+}$ in the solution was less than $1 \%$ at any time. Therefore, the slight removal of $\mathrm{Cu}^{2+}$ by $\mathrm{CO}_{3} \bullet \mathrm{Mg}-\mathrm{Al} \mathrm{LDH}$ may be attributable to the coprecipitation of $\mathrm{Cu}^{2+}$ with the dissolved $\mathrm{Al}^{3+}$ to form $\mathrm{Cu}-\mathrm{Al} \mathrm{LDH} . \mathrm{Mg}^{2+}$ dissolved from EDTA $\bullet \mathrm{Mg}-\mathrm{Al} \mathrm{LDH}$ as well as $\mathrm{CO}_{3} \bullet \mathrm{Mg}-\mathrm{Al} \mathrm{LDH}$, while $\mathrm{Al}^{3+}$ was detected to a substantially lower concentration than $\mathrm{Mg}^{2+}$ in the solution. Consequently, the uptake of $\mathrm{Cu}^{2+}$ by EDTA $\bullet \mathrm{Mg}-\mathrm{Al} \mathrm{LDH}$ was attributed to both the formation of chelate complexes with EDTA4- in the interlayer and coprecipitation with the dissolved $\mathrm{Al}^{3+}$. Note that EDTA $\bullet \mathrm{Mg}-$ $\mathrm{Al} \mathrm{LDH}$ removed $\mathrm{Cu}^{2+}$ from an aqueous solution with an initial concentration of $64 \mathrm{mg} / \mathrm{L}$ to less than the effluent standards in Japan $(3 \mathrm{mg} / \mathrm{L})$ in a short span of $10 \mathrm{~min}$. For EDTA $\bullet \mathrm{Mg}-$ $\mathrm{Al} \mathrm{LDH}$, the concentration of $\mathrm{Cd}^{2+}$ decreased with time, and the concentration decreased quickly with increasing EDTA4- $/ \mathrm{Cd}^{2+}$ molar ratio. The concentration decreased to $0.02 \mathrm{mM}$ $(2 \mathrm{mg} / \mathrm{L})$ in $10 \mathrm{~min}$ at an $\mathrm{EDTA}^{4-} / \mathrm{Cd}^{2+}$ molar ratio of $2.0\left(17 \mathrm{mg}-\mathrm{Cd}^{2+} / \mathrm{g}-\mathrm{EDTA} \bullet \mathrm{Mg}-\mathrm{Al}\right.$ $\mathrm{LDH})$. However, for $\mathrm{CO}_{3} \bullet \mathrm{Mg}-\mathrm{Al} \mathrm{LDH}$, the decrease in the concentration was extremely slow, and the concentration was still $0.93 \mathrm{mM}(104 \mathrm{mg} / \mathrm{L})$ after $10 \mathrm{~min}\left(1 \mathrm{mg}-\mathrm{Cd}^{2+} / \mathrm{g}-\right.$ $\left.\mathrm{CO}_{3} \bullet \mathrm{Mg}-\mathrm{Al} \mathrm{LDH}\right)$. The differences in the removal of $\mathrm{Cd}^{2+}$ were also attributed to the function of EDTA ${ }^{4-}$ in the interlayer of EDTA $\bullet \mathrm{Mg}-\mathrm{Al} \mathrm{LDH}$. Note that the concentration of $\mathrm{Cd}^{2+}$ decreased rapidly from $112 \mathrm{mg} / \mathrm{L}$ to less than $1 \mathrm{mg} / \mathrm{L}$ at an EDTA ${ }^{4-} / \mathrm{Cd}^{2+}$ molar ratio of 2.0 in $15 \mathrm{~min}$. For the $\mathrm{Cu}-\mathrm{Cd}$ mixed chloride solution, the concentration of $\mathrm{Cu}^{2+}$ decreased with time more rapidly than that of $\mathrm{Cd}^{2+}$, confirming the preferential uptake of $\mathrm{Cu}^{2+}$ over $\mathrm{Cd}^{2+}$ from the mixed solution by EDTA $\bullet \mathrm{Mg}-\mathrm{Al} \mathrm{LDH}$. This preferential uptake was probably due to the difference between the stabilities of $\mathrm{Cu}(\mathrm{EDTA})^{2-}$ and $\mathrm{Cd}(\mathrm{EDTA})^{2-}$. The chelate formation constants for $\mathrm{Cu}(\mathrm{EDTA})^{2-}$ and $\mathrm{Cd}(\mathrm{EDTA})^{2-}$ are reported to be 18.8 and 16.5; i.e., $\mathrm{Cu}(\mathrm{EDTA})^{2-}$ is more stable than $\mathrm{Cd}(\mathrm{EDTA})^{2-}$. Thus, it is believed that EDTA $^{4-}$ in the interlayer formed the chelate complex with $\mathrm{Cu}^{2+}$ preferentially over $\mathrm{Cd}^{2+}$ in the mixed solution. From these results, it can be deduced that EDTA4- maintains its chelating function even when intercalated in the interlayer of $\mathrm{Mg}-\mathrm{Al} \mathrm{LDH}$.

Perez et al. (2006) examined the uptake of $\mathrm{Cu}^{2+}, \mathrm{Cd}^{2+}$, and $\mathrm{Pb}^{2+}$ on $\mathrm{Zn}-\mathrm{Al} \mathrm{LDH}$ intercalated with EDTA. EDTA $\bullet \mathrm{Zn}-\mathrm{Al} \mathrm{LDH}$ was obtained from $\mathrm{NO}_{3} \bullet \mathrm{Zn}-\mathrm{Al} \mathrm{LDH}$ using the anion exchange method. The uptake of $\mathrm{Cu}^{2+}, \mathrm{Cd}^{2+}$, and $\mathrm{Pb}^{2+}$ from the aqueous solutions was due to chelation between EDTA and metal cations. The shape of the adsorption isotherms suggests specific interaction and high host-guest affinity. At $\mathrm{pH} 5.5$ and an initial concentration of $10 \mathrm{mM}$, the amounts adsorbed were 1117, 375, and $871 \mu \mathrm{mol} / \mathrm{g}$ for $\mathrm{Cu}^{2+}$, $\mathrm{Cd}^{2+}$, and $\mathrm{Pb}^{2+}$, respectively. Kulyukhin et al. (2008) examined the adsorption of $\mathrm{Sr}$ radionuclides from the aqueous phase on EDTA $\bullet \mathrm{Mg}-\mathrm{Al} \mathrm{LDH}$. The adsorption was apparently associated with the complexation of $\mathrm{Sr}^{2+}$ with $\left[\mathrm{H}_{2}(\mathrm{EDTA})\right]^{2-}$ incorporated in the EDTA $\bullet \mathrm{Mg}-\mathrm{Al} \mathrm{LDH}$. Rojas et al. (2009) examined EDTA-modified $\mathrm{Zn}-\mathrm{Al} \mathrm{LDH}$ as a $\mathrm{Cu}^{2+}$ scavenger based on removal kinetics and sorbent stability. They noted that the exchange process between $\mathrm{NO}_{3} \cdot \mathrm{Zn}-\mathrm{Al} \mathrm{LDH}$ and $\left[\mathrm{H}_{2}(\mathrm{EDTA})\right]^{2-}$ anions takes place with partial erosion of the layers, causing the intercalation of [Zn(EDTA) $]^{2-}$ anions instead of the ligand. They insisted that the uptake of $\left[\mathrm{Cu}\left(\mathrm{H}_{2} \mathrm{O}\right)_{6}\right]^{2+}$ by $[\mathrm{Zn}(\text { EDTA })]^{2-}$ intercalated in sorbent-LDH results from an exchange reaction between chelated zinc cations in the interlayer and copper cations in solution. Gasser and Aly (2009) examined the kinetic and adsorption mechanisms of $\mathrm{Cu}^{2+}$ and $\mathrm{Pb}^{2+}$ using EDTA $\bullet \mathrm{Mg}-\mathrm{Fe} \mathrm{LDH}$. $\mathrm{Cu}^{2+}$ and $\mathrm{Pb}^{2+}$ were adsorbed by EDTA $\bullet \mathrm{Mg}-\mathrm{Fe}$ LDH due to chelation with EDTA from the LDH interlayer. The adsorption of $\mathrm{Cu}^{2+}$ was higher than that of $\mathrm{Pb}^{2+}$; this was attributed to the stability constant of $[\mathrm{Cu}(\mathrm{EDTA})]^{2-}$, which 
is higher than that of $[\mathrm{Pb}(\mathrm{EDTA})]^{2-}$. The shape of the adsorption isotherm suggests specific interaction and high affinity. The kinetics of the adsorption of $\mathrm{Cu}^{2+}$ onto EDTA $\bullet \mathrm{Mg}-\mathrm{Fe} \mathrm{LDH}$ follows first-order reversible kinetics, and the values of the first-order rate constants increased with increasing temperature. The chemisorption step may be the rate-limiting step of adsorption from solution.

In our previous research (Kameda et al., 2005a), the $\mathrm{pH}$ of the solution during uptake of $\mathrm{Cu}^{2+}$ and $\mathrm{Cd}^{2+}$ by EDTA $\bullet \mathrm{Mg}-\mathrm{Al} \mathrm{LDH}$ was adjusted to 5.0 by the addition of $0.1 \mathrm{~mol} / \mathrm{L}$ acid; this $\mathrm{pH}$ value was maintained to prevent precipitation of the hydroxides of $\mathrm{Cu}^{2+}$ and $\mathrm{Cd}^{2+}$. However, this method resulted in the dissolution of $\mathrm{Mg}^{2+}$ from EDTA $\bullet \mathrm{Mg}-\mathrm{Al} \mathrm{LDH}$ because of the increasing acidity as $\mathrm{Mg}^{2+}$ precipitated as $\mathrm{Mg}(\mathrm{OH})_{2}$ at $\mathrm{pH}>10$. Therefore, $\mathrm{Cu}^{2+}$ was selected as the divalent metal ion of the LDH host layer because the hydrolysis product of $\mathrm{Cu}^{2+}\left(\mathrm{pK}_{\mathrm{sp}}=17.3\right)$ is less soluble than that of $\mathrm{Mg}^{2+}\left(\mathrm{pK}_{\mathrm{sp}}=11.2\right)$. Recently, we prepared $\mathrm{Cu}-\mathrm{Al} \mathrm{LDH}$ intercalated with EDTA (EDTA $\bullet \mathrm{Cu}-\mathrm{Al} \mathrm{LDH})$ by suspending $\mathrm{Cu}-\mathrm{Al}$ oxide, obtained by calcination of $\mathrm{CO}_{3} \bullet \mathrm{Cu}-\mathrm{Al} \mathrm{LDH}$, in EDTA solution (Kameda et al., 2011). The reconstruction of $\mathrm{Cu}-\mathrm{Al}$ oxide to $\mathrm{Cu}-\mathrm{Al} \mathrm{LDH}$ was promoted with increasing temperature and time. The reaction at a $\mathrm{pH}$ of $\sim 8$ suggests that $[\mathrm{H}(\mathrm{EDTA})]^{3-}$ was intercalated in the interlayer of $\mathrm{Cu}-\mathrm{Al} \mathrm{LDH}$. EDTA $\bullet \mathrm{Cu}-\mathrm{Al} \mathrm{LDH}$ was found to take up rare metal ions such as $\mathrm{Sc}^{3+}$ and $\mathrm{La}^{3+}$ in an aqueous solution at a $\mathrm{pH}$ of $\sim 6-6.5$. The uptake of $\mathrm{Sc}^{3+}$ was caused not only by the chelating function of [H(EDTA) $]^{3-}$ in the interlayer but also by the chemical behavior of $\mathrm{Cu}-\mathrm{Al} \mathrm{LDH}$ itself. On the other hand, the uptake of $\mathrm{La}^{3+}$ was caused only by the chelating function of $[\mathrm{H}(\mathrm{EDTA})]^{3-}$ in the interlayer. $[\mathrm{H}(\mathrm{EDTA})]^{3-}$ in the interlayer of $\mathrm{EDTA} \bullet \mathrm{Cu}-\mathrm{Al} \mathrm{LDH}$ formed a chelate complex with $\mathrm{Sc}^{3+}$ more preferentially than with $\mathrm{La}^{3+}$.

\subsection{LDH intercalated with carboxylates}

We examined organic acids for leaching heavy metals from fly ash generated by gasification and melting furnace treatments for municipal solid wastes (Saito et al., 2007). Organic acids such as citric, malic, and tartaric acids were found to be effective for leaching heavy metals due to the formation of chelate complexes between the metals and acids on the surface of the fly ash. Since citric, malic, and tartaric acids have the capacity for heavy metal extraction, $\mathrm{Mg}-\mathrm{Al}$ LDHs intercalated with citrate $\left(\mathrm{C}_{6} \mathrm{H}_{5} \mathrm{O}_{7}{ }^{3-}\right)$, malate $\left(\mathrm{C}_{4} \mathrm{H}_{4} \mathrm{O}_{5}{ }^{2-}\right)$, and tartrate $\left(\mathrm{C}_{4} \mathrm{H}_{4} \mathrm{O}_{6}{ }^{2-}\right)$ anions can be expected to take up heavy metal ions from aqueous solution into the interlayers. Citric, malic, and tartaric acids exist abundantly in nature, and, therefore, the corresponding organic acid anion-intercalated $\mathrm{Mg}-\mathrm{Al} \mathrm{LDHs}$ are more appropriate for commercial-scale applications than EDTA $\bullet \mathrm{Mg}-\mathrm{Al} \mathrm{LDH}$.

Meyn et al. (1990) used the anion exchange method to prepare Mg-Al LDH composite materials with intercalated $\mathrm{C}_{6} \mathrm{H}_{5} \mathrm{O}_{7}{ }^{3-}$ and $\mathrm{C}_{4} \mathrm{H}_{4} \mathrm{O}_{6}{ }^{2-}$, whereas Zhang et al. (2004) prepared $\mathrm{Mg}-\mathrm{Al} \mathrm{LDH}$ intercalated with $\mathrm{C}_{6} \mathrm{H}_{5} \mathrm{O}_{7}^{3-}, \mathrm{C}_{4} \mathrm{H}_{4} \mathrm{O}_{5}^{2-}$, and $\mathrm{C}_{4} \mathrm{H}_{4} \mathrm{O}_{6}{ }^{2-}$ through a unique method involving the dissolution of $\mathrm{CO}_{3} \bullet \mathrm{Mg}-\mathrm{Al} \mathrm{LDH}$ to form the corresponding carboxylic acid followed by precipitation in basic solution. Tronto et al. $(2001,2004)$ used coprecipitation to form $\mathrm{Mg}-\mathrm{Al} \mathrm{LDH}$ intercalated with $\mathrm{C}_{6} \mathrm{H}_{5} \mathrm{O}_{7}^{3-}$.

We prepared $\mathrm{Mg}-\mathrm{Al} \mathrm{LDHs}$ intercalated with $\mathrm{C}_{6} \mathrm{H}_{5} \mathrm{O}_{7}{ }^{3-}, \mathrm{C}_{4} \mathrm{H}_{4} \mathrm{O}_{5}{ }^{2-}$, and $\mathrm{C}_{4} \mathrm{H}_{4} \mathrm{O}_{6}{ }^{2-}$ by coprecipitation via dropwise addition of a $\mathrm{Mg}-\mathrm{Al}$ nitrate solution to citrate, malate, and tartrate solutions, respectively, at a constant $\mathrm{pH}$ of 10.5 and investigated the effects of the organic anion concentrations on the formation of the composites (Kameda et al., 2009a). For $\mathrm{Mg}-\mathrm{Al} \mathrm{LDH}$ intercalated with citrate (citrate $\bullet \mathrm{Mg}-\mathrm{Al} \mathrm{LDH}$ ), low solution concentrations of $\mathrm{C}_{6} \mathrm{H}_{5} \mathrm{O}_{7}{ }^{3-}$ resulted in intercalation of $\mathrm{C}_{6} \mathrm{H}_{5} \mathrm{O}_{7}{ }^{3-}$ into the interlayer at a $26^{\circ}$ angle relative to the 
brucite-like layers of $\mathrm{Mg}-\mathrm{Al} \mathrm{LDH}$. At higher $\mathrm{C}_{6} \mathrm{H}_{5} \mathrm{O}_{7}^{3-}$ concentrations, both $\mathrm{Mg}\left(\mathrm{C}_{6} \mathrm{H}_{5} \mathrm{O}_{7}\right)^{-}$ and $\mathrm{C}_{6} \mathrm{H}_{5} \mathrm{O}_{7}{ }^{3-}$ were intercalated into the interlayer with an irregular orientation, and $\mathrm{C}_{6} \mathrm{H}_{5} \mathrm{O}_{7}{ }^{3-}$ adsorbed to the surface of the $\mathrm{Mg}-\mathrm{Al} \mathrm{LDH}$. For Mg-Al LDHs intercalated with malate and tartrate (malate $\bullet \mathrm{Mg}-\mathrm{Al} \mathrm{LDH}$ and tartrate $\bullet \mathrm{Mg}-\mathrm{Al} \mathrm{LDH}$ ), the intercalated $\mathrm{C}_{4} \mathrm{H}_{4} \mathrm{O}_{5}{ }^{2-}$ and $\mathrm{C}_{4} \mathrm{H}_{4} \mathrm{O}_{6}{ }^{2-}$ were also oriented at an angle of $26^{\circ}$ relative to the brucite-like layers of the $\mathrm{Mg}-\mathrm{Al} \mathrm{LDH}$, regardless of solution concentration. The amount of intercalated $\mathrm{C}_{4} \mathrm{H}_{4} \mathrm{O}_{5}{ }^{2}$ for malate $\bullet \mathrm{Mg}-\mathrm{Al} \mathrm{LDH}$ was governed solely by the electric charge balance in $\mathrm{Mg}-$ $\mathrm{Al} \mathrm{LDH}$ and was not affected by increased solution concentration. However, increasing the solution concentration of $\mathrm{C}_{4} \mathrm{H}_{4} \mathrm{O}_{6}{ }^{2-}$ during the formation of tartrate $\bullet \mathrm{Mg}-\mathrm{Al} \mathrm{LDH}$ resulted in both interlayer intercalation and adsorption of $\mathrm{C}_{4} \mathrm{H}_{4} \mathrm{O}_{6}{ }^{2-}$ to the surface of the composite. These $\mathrm{Mg}-\mathrm{Al} \mathrm{LDHs}$ were found to take up $\mathrm{Cu}^{2+}$ and $\mathrm{Cd}^{2+}$ rapidly from an aqueous solution at a constant $\mathrm{pH}$ of 5.0 (Kameda et al., 2008a). This capacity was mainly attributed to the formation of citrate-metal, malate-metal, and tartrate-metal complexes in the interlayers of the $\mathrm{Mg}-\mathrm{Al} \mathrm{LDHs}$. The uptake of $\mathrm{Cu}^{2+}$ increased in the order malate $\bullet \mathrm{Mg}-\mathrm{Al} \mathrm{LDH}<$ tartrate $\bullet \mathrm{Mg}-\mathrm{Al} \mathrm{LDH}<$ citrate $\bullet \mathrm{Mg}-\mathrm{Al} \mathrm{LDH}$. The uptake of $\mathrm{Cd}^{2+}$ increased in the order malate $\bullet \mathrm{Mg}-\mathrm{Al} \mathrm{LDH}<$ tartrate $\bullet \mathrm{Mg}-\mathrm{Al} \mathrm{LDH}=$ citrate $\bullet \mathrm{Mg}-\mathrm{Al} \mathrm{LDH}$. These differences in $\mathrm{Cu}^{2+}$ and $\mathrm{Cd}^{2+}$ uptake were attributable to differences in the stabilities of the citrate-metal, malate-metal, and tartrate-metal complexes. These results indicate that $\mathrm{C}_{6} \mathrm{H}_{5} \mathrm{O}_{7}^{3-}, \mathrm{C}_{4} \mathrm{H}_{4} \mathrm{O}_{5}{ }^{2-}$, and $\mathrm{C}_{4} \mathrm{H}_{4} \mathrm{O}_{6}{ }^{2-}$ were adequately active as chelating agents in the interlayers of $\mathrm{Mg}-\mathrm{Al} \mathrm{LDHs}$.

We also examined the kinetics of the uptake of $\mathrm{Cu}^{2+}$ and $\mathrm{Cd}^{2+}$ by citrate $\bullet \mathrm{Mg}-\mathrm{Al} \mathrm{LDH}$, malate $\bullet \mathrm{Mg}-\mathrm{Al} \mathrm{LDH}$, and tartrate $\bullet \mathrm{Mg}-\mathrm{Al} \mathrm{LDH}$ (Kameda et al., 2010a). The Mg-Al LDHs were added to $500 \mathrm{~mL}$ of $1.0 \mathrm{mmol} / \mathrm{L} \mathrm{Cu}\left(\mathrm{NO}_{3}\right)_{2}$ or $\mathrm{Cd}\left(\mathrm{NO}_{3}\right)_{2}$ solution. The molar ratio of citrate, malate, or tartrate in $\mathrm{Mg}-\mathrm{Al} \mathrm{LDH}$ to $\mathrm{Cu}^{2+}$ or $\mathrm{Cd}^{2+}$ in the nitrate solution was set to 1.0. The resultant suspension was left to stand at 10,20 , and $30^{\circ} \mathrm{C}$ for $60 \mathrm{~min}$ with stirring at a constant $\mathrm{pH}$ of 5.0. The concentrations of $\mathrm{Cu}^{2+}$ and $\mathrm{Cd}^{2+}$ decreased with time and increasing temperature. The accelerated rate of $\mathrm{Cu}^{2+}$ and $\mathrm{Cd}^{2+}$ uptake by the $\mathrm{Mg}-\mathrm{Al} \mathrm{LDH}$ at high temperatures implies that the uptake reactions were governed by chemical reactions rather than mass transfer. The reactions were examined kinetically based on the chemical equation. The uptake of $\mathrm{Cu}^{2+}$ by citrate $\bullet \mathrm{Mg}-\mathrm{Al} \mathrm{LDH}$ was attributed to the 1:1 chelation between $\mathrm{Cu}^{2+}$ and citrate as follows:

$$
\mathrm{C}_{6} \mathrm{H}_{5} \mathrm{O}_{7}^{3-}+\mathrm{Cu}^{2+} \rightarrow \mathrm{Cu}\left(\mathrm{C}_{6} \mathrm{H}_{5} \mathrm{O}_{7}\right)^{-}
$$

This reaction gives the following rate equation:

$$
d\left[\mathrm{Cu}\left(\mathrm{C}_{6} \mathrm{H}_{5} \mathrm{O}_{7}\right)^{-}\right] / d t=k\left[\mathrm{C}_{6} \mathrm{H}_{5} \mathrm{O}_{7}^{3-}\right]\left[\mathrm{Cu}^{2+}\right]
$$

where $t$ is the reaction time, and $k$ is the apparent rate constant. Because

$$
d\left[\mathrm{Cu}\left(\mathrm{C}_{6} \mathrm{H}_{5} \mathrm{O}_{7}\right)^{-}\right] / d t=d\left[\mathrm{Cu}^{2+}\right] / d t \text { and }\left[\mathrm{C}_{6} \mathrm{H}_{5} \mathrm{O}_{7}^{3-}\right] /\left[\mathrm{Cu}^{2+}\right]=1,-d\left[\mathrm{Cu}^{2+}\right] / d t=k\left[\mathrm{Cu}^{2+}\right]^{2}
$$

The integration of Eq. (6) gives

$$
1 /\left[\mathrm{Cu}^{2+}\right]=k t+1
$$

Assuming that $x$ is the degree of $\mathrm{Cu}^{2+}$ uptake, $\left[\mathrm{Cu}^{2+}\right]$ can be expressed as $1-x$ because the initial $\mathrm{Cu}^{2+}$ concentration was $1.0 \mathrm{mmol} / \mathrm{L}$. Equation 7 can be converted to Eq. (8):

$$
1 /(1-x)=k t+1
$$


The uptake rate of $\mathrm{Cu}^{2+}$ by citrate $\bullet \mathrm{Mg}-\mathrm{Al} \mathrm{LDH}$ was determined from Eq. (8), and the plot of $1 /(1-x)$ versus $t$ is shown in Fig. 2.

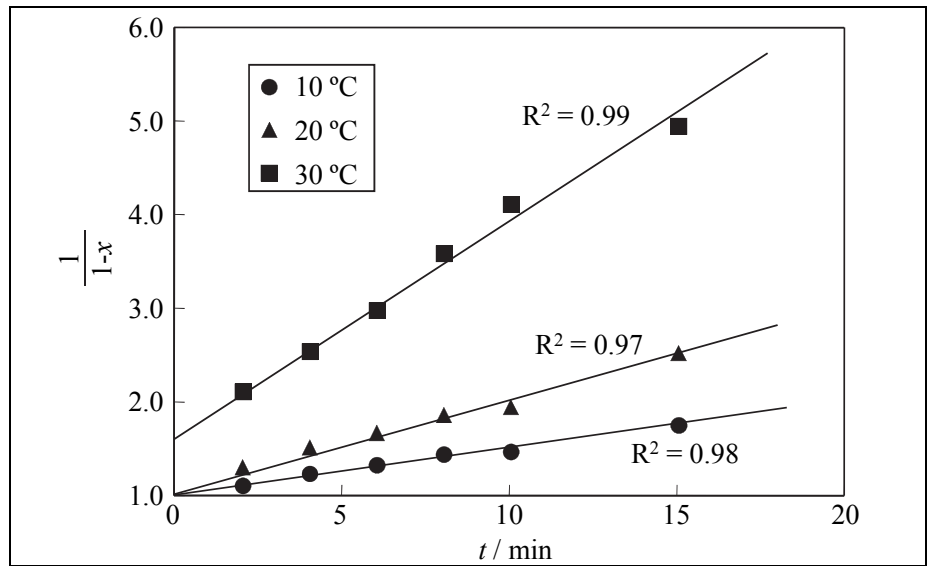

Fig. 2. Plot of $1 /(1-x)$ vs. $t$ for uptake of $\mathrm{Cu}^{2+}$ by citrate $\bullet \mathrm{Mg}-\mathrm{Al} \mathrm{LDH}$.

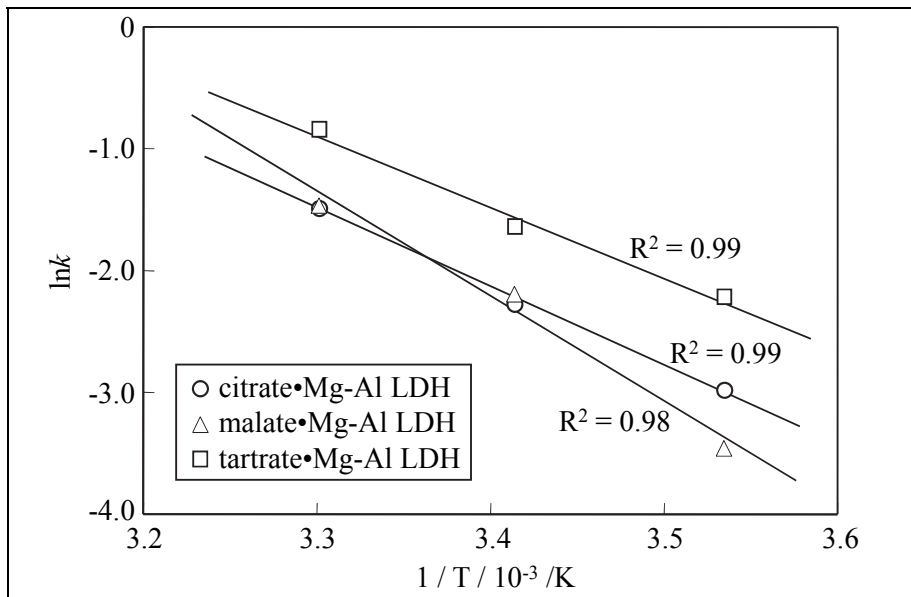

Fig. 3. Arrhenius plot of the apparent rate constant for uptake of $\mathrm{Cu}^{2+}$ by $\mathrm{Mg}-\mathrm{Al} \mathrm{LDHs}$.

Good linearity was obtained at each temperature, indicating that the reaction rate could be expressed by Eq. (5). At $30^{\circ} \mathrm{C}$, the value of the intercept was not 1.0, suggesting that the precipitation rate of $\mathrm{Cu}-\mathrm{Al} \mathrm{LDH}$, which formed between a few $\mathrm{Cu}^{2+}$ cations and dissolved $\mathrm{Al}^{3+}$, was very fast. The apparent rate constants at 10,20 , and $30^{\circ} \mathrm{C}$ were $5.1 \times 10^{-2}, 1.0 \times 10^{-}$ 1 , and $2.3 \times 10^{-1}$, respectively. Thus, the apparent rate constant increased with increasing temperature. An Arrhenius plot of $k$, determined from the slopes of the straight lines in Fig. 2 , is shown in Fig. 3; this plot yields an apparent activation energy of $53.1 \mathrm{~kJ} \cdot \mathrm{mol}^{-1}$. This value confirms that the uptake of $\mathrm{Cu}^{2+}$ by citrate $\bullet \mathrm{Mg}-\mathrm{Al} \mathrm{LDH}$ proceeded under chemical reaction control because the apparent activation energy for the chemical reaction was larger than $30 \mathrm{~kJ} \cdot \mathrm{mol}^{-1}$. The uptake of $\mathrm{Cu}^{2+}$ by this LDH occurred via chelation between $\mathrm{Cu}^{2+}$ and 
citrate. The uptake of $\mathrm{Cu}^{2+}$ by malate $\bullet \mathrm{Mg}-\mathrm{Al} \mathrm{LDH}$ was attributed to the $2: 2$ chelation between $\mathrm{Cu}^{2+}$ and malate and is expressed as

$$
2 \mathrm{C}_{4} \mathrm{H}_{4} \mathrm{O}_{5}{ }^{2-}+2 \mathrm{Cu}^{2+} \rightarrow\left[\mathrm{Cu}_{2}\left(\mathrm{C}_{4} \mathrm{H}_{3} \mathrm{O}_{5}\right)\left(\mathrm{C}_{4} \mathrm{H}_{4} \mathrm{O}_{5}\right)\right]^{-}+\mathrm{H}^{+}
$$

This reaction gives the following rate equation:

$$
d\left[\left[\mathrm{Cu}_{2}\left(\mathrm{C}_{4} \mathrm{H}_{3} \mathrm{O}_{5}\right)\left(\mathrm{C}_{4} \mathrm{H}_{4} \mathrm{O}_{5}\right)\right]^{-}\right] / d t=k\left[\mathrm{C}_{4} \mathrm{H}_{4} \mathrm{O}_{5}{ }^{2-}\right]^{2}\left[\mathrm{Cu}^{2+}\right]^{2}
$$

where $t$ is the reaction time, and $k$ is the apparent rate constant. Because

$$
\begin{gathered}
d\left[\left[\mathrm{Cu}_{2}\left(\mathrm{C}_{4} \mathrm{H}_{3} \mathrm{O}_{5}\right)\left(\mathrm{C}_{4} \mathrm{H}_{4} \mathrm{O}_{5}\right)\right]^{-}\right] / d t=-(1 / 2) \bullet d\left[\mathrm{Cu}^{2+}\right] / d t \text { and }\left[\mathrm{C}_{4} \mathrm{H}_{4} \mathrm{O}_{5}{ }^{2-}\right] /\left[\mathrm{Cu}^{2+}\right]=1, \\
-(1 / 2) \bullet d[\mathrm{Cu} 2+] / d t=\mathrm{k}[\mathrm{Cu} 2+] 4
\end{gathered}
$$

Integration of Eq. (11) gives

$$
(1 / 6) \cdot\left[\mathrm{Cu}^{2+}\right]^{-3}=k t+1 / 6
$$

Equation 12 can be converted to Eq. (13):

$$
(1 / 6) \bullet(1-x)^{-3}=k t+1 / 6
$$

The uptake rate of $\mathrm{Cu}^{2+}$ by malate $\bullet \mathrm{Mg}-\mathrm{Al} \mathrm{LDH}$ was determined from Eq. (13). The plot of $(1 / 6) \bullet(1-x)^{-3}$ versus $t$ showed good linearity at each temperature, indicating that the reaction rate could be expressed by Eq. (10). At $30^{\circ} \mathrm{C}$, the value of the intercept was not $1 / 6$. This was due to the very fast precipitation rate of $\mathrm{Cu}-\mathrm{Al} \mathrm{LDH}$. The apparent rate constants at 10,20 , and $30^{\circ} \mathrm{C}$ were $3.1 \times 10^{-2}, 1.1 \times 10^{-1}$, and $2.3 \times 10^{-1}$, respectively. The apparent rate constant increased with increasing temperature. An Arrhenius plot of $k$, determined from the slopes of the straight lines, is also shown in Fig. 3. The apparent activation energy in this case was $71.2 \mathrm{~kJ} \cdot \mathrm{mol}^{-1}$, confirming that the uptake of $\mathrm{Cu}^{2+}$ by malate $\cdot \mathrm{Mg}-\mathrm{Al} \mathrm{LDH}$ proceeded under chemical reaction control. Furthermore, the uptake of $\mathrm{Cu}^{2+}$ by this $\mathrm{LDH}$ occurred via chelation between $\mathrm{Cu}^{2+}$ and malate. The uptake of $\mathrm{Cu}^{2+}$ by tartrate $\bullet \mathrm{Mg}-\mathrm{Al}$ $\mathrm{LDH}$ was attributed to the 2:2 chelation between $\mathrm{Cu}^{2+}$ and tartrate, and is expressed as

$$
2 \mathrm{C}_{4} \mathrm{H}_{4} \mathrm{O}_{6}{ }^{2-}+2 \mathrm{Cu}^{2+} \rightarrow\left[\mathrm{Cu}_{2}\left(\mathrm{C}_{4} \mathrm{H}_{3} \mathrm{O}_{6}\right)\left(\mathrm{C}_{4} \mathrm{H}_{4} \mathrm{O}_{6}\right)\right]^{-}+\mathrm{H}^{+}
$$

This reaction gives the following rate equation:

$$
d\left[\left[\mathrm{Cu}_{2}\left(\mathrm{C}_{4} \mathrm{H}_{3} \mathrm{O}_{6}\right)\left(\mathrm{C}_{4} \mathrm{H}_{4} \mathrm{O}_{6}\right)\right]^{-}\right] / d t=k\left[\mathrm{C}_{4} \mathrm{H}_{4} \mathrm{O}_{6}{ }^{2-}\right]^{2}\left[\mathrm{Cu}^{2+}\right]^{2}
$$

Because Eq. (15) is similar to Eq. (10), it can be converted to Eq. (13). The uptake rate of $\mathrm{Cu}^{2+}$ by tartrate $\bullet \mathrm{Mg}-\mathrm{Al} \mathrm{LDH}$ was determined from Eq. (13). The reaction rate in this case could be expressed by Eq. (15) because the plot of $(1 / 6) \bullet(1-x)^{-3}$ versus $t$ gave good linearity at each temperature. The apparent rate constants at 10,20 , and $30^{\circ} \mathrm{C}$ were $1.1 \times 10^{-1}, 1.9 \times 10^{-1}$, and $4.3 \times 10^{-1}$, respectively. An Arrhenius plot of $k$, determined from the slopes of the straight lines, is also shown in Fig. 3; in this case, the apparent activation energy is 48.9 $\mathrm{kJ} \cdot \mathrm{mol}^{-1}$. Thus, it was confirmed that the uptake of $\mathrm{Cu}^{2+}$ by tartrate $\bullet \mathrm{Mg}-\mathrm{Al} \mathrm{LDH}$ proceeded under chemical reaction control. Furthermore, the uptake of $\mathrm{Cu}^{2+}$ by this $\mathrm{LDH}$ occurred via chelation between $\mathrm{Cu}^{2+}$ and tartrate. Similarly, the uptake of $\mathrm{Cd}^{2+}$ by three types of $\mathrm{Mg}-\mathrm{Al}$ LDHs was also examined kinetically based on the chemical equation. For citrate $\bullet \mathrm{Mg}-\mathrm{Al}$ $\mathrm{LDH}$, the apparent rate constants at 10,20 , and $30^{\circ} \mathrm{C}$ were $5.9 \times 10^{-3}, 1.0 \times 10^{-2}$, and $2.7 \times 10^{-2}$, 
respectively; thus, it is clear that the rate constant increased with increasing temperature. The apparent activation energy was calculated to be $53.6 \mathrm{~kJ} \cdot \mathrm{mol}^{-1}$. This value confirms that the uptake of $\mathrm{Cd}^{2+}$ by citrate $\bullet \mathrm{Mg}-\mathrm{Al} \mathrm{LDH}$ proceeded under chemical reaction control. The uptake of $\mathrm{Cd}^{2+}$ by this $\mathrm{LDH}$ occurred via 1:1 chelation between $\mathrm{Cd}^{2+}$ and citrate. For malate $\bullet \mathrm{Mg}-\mathrm{Al} \mathrm{LDH}$, the apparent rate constants at 10,20 , and $30^{\circ} \mathrm{C}$ were $1.3 \times 10^{-2}, 2.3 \times$ $10^{-2}$, and $5.5 \times 10^{-2}$, respectively. The apparent activation energy was calculated to be 50.8 $\mathrm{kJ} \cdot \mathrm{mol}^{-1}$, confirming that the uptake of $\mathrm{Cd}^{2+}$ by malate $\bullet \mathrm{Mg}-\mathrm{Al} \mathrm{LDH}$ proceeded under chemical reaction control. Furthermore, the uptake of $\mathrm{Cd}^{2+}$ by this $\mathrm{LDH}$ occurred via 1:2 chelation between $\mathrm{Cd}^{2+}$ and malate. For tartrate $\bullet \mathrm{Mg}-\mathrm{Al} \mathrm{LDH}$, the apparent rate constants at 10,20 , and $30^{\circ} \mathrm{C}$ were $5.8 \times 10^{-3}, 2.0 \times 10^{-2}$, and $1.2 \times 10^{-1}$, respectively. An Arrhenius plot of $k$ provides an apparent activation energy of $106.5 \mathrm{~kJ} \cdot \mathrm{mol}^{-1}$. This value confirms that the uptake of $\mathrm{Cd}^{2+}$ by tartrate $\bullet \mathrm{Mg}-\mathrm{Al} \mathrm{LDH}$ proceeded under chemical reaction control. Furthermore, the uptake of $\mathrm{Cd}^{2+}$ by tartrate $\bullet \mathrm{Mg}-\mathrm{Al} \mathrm{LDH}$ occurred via 1:2 chelation between $\mathrm{Cd}^{2+}$ and tartrate. To summarize, the reaction simply proceeded via chelation at a certain rate, which was different for each combination.

The citrate-modified $\mathrm{Mg}-\mathrm{Al} \mathrm{LDH}$ was suggested to have citrate anions not only intercalated in the interlayer but also adsorbed on the surface (Kameda et al., 2008a, 2009a). Because Mg$\mathrm{Al} \mathrm{LDH}$ has the basic structure of $\mathrm{Mg}(\mathrm{OH})_{2}$, organic acid anions such as citrate are likely to be adsorbed on the surface of $\mathrm{Mg}(\mathrm{OH})_{2}$. The organic acid anion-adsorbed $\mathrm{Mg}(\mathrm{OH})_{2}$ is also expected to take up heavy metal ions from aqueous solution. Furthermore, by coprecipitation as well as $\mathrm{Mg}-\mathrm{Al} \mathrm{LDHs}$ intercalated with organic anions, new layered magnesium hydroxides modified with organic acid anions may be produced. Narita et al. and Tagaya et al. have previously reported the formation of layered zinc hydroxides modified with aliphatic carboxylates, aromatic carboxylates, anionic surfactants, and organic oxychlorides (Tagaya et al., 1996; Takahashi et al., 1997; Ogata et al., 1998; Ogata et al., 2000). Hence, layered magnesium hydroxides modified with organic acid anions are also expected to take up heavy metal ions from aqueous solutions. $\mathrm{Mg}\left(\mathrm{NO}_{3}\right)_{2}$ solution was added dropwise to citrate, malate, and tartrate solutions at $30^{\circ} \mathrm{C}$ under mild agitation (Kameda et al., 2009b). Solution $\mathrm{pH}$ was adjusted to 10.5 by addition of $\mathrm{NaOH}$ solution. After addition of $\mathrm{Mg}\left(\mathrm{NO}_{3}\right)_{2}$ solution, the resultant suspensions were incubated at $30^{\circ} \mathrm{C}$ for $1 \mathrm{~h}$. For malate and tartrate, new layered magnesium hydroxides in which brucite layers were bridged by $\mathrm{C}_{4} \mathrm{H}_{4} \mathrm{O}_{5}{ }^{2-}$ and $\mathrm{C}_{4} \mathrm{H}_{4} \mathrm{O}_{6}{ }^{2-}$ were prepared. The $\mathrm{C}_{4} \mathrm{H}_{4} \mathrm{O}_{5}{ }^{2-}$ and $\mathrm{C}_{4} \mathrm{H}_{4} \mathrm{O}_{6}{ }^{2-}$ may also have been absorbed on the surfaces of the hydroxides. For citrate, $\mathrm{Mg}(\mathrm{OH})_{2}$ with absorbed $\mathrm{C}_{6} \mathrm{H}_{5} \mathrm{O}_{7}{ }^{3-}$ was produced. These materials were found to take up $\mathrm{Cu}^{2+}$ rapidly from an aqueous solution at a constant $\mathrm{pH}$ of 5.0. The $\mathrm{Cu}^{2+}$ uptake was attributed to the formation of chelate complexes of $\mathrm{Cu}^{2+}$ with $\mathrm{C}_{6} \mathrm{H}_{5} \mathrm{O}_{7}{ }^{3-}, \mathrm{C}_{4} \mathrm{H}_{4} \mathrm{O}_{5}{ }^{2-}$, and $\mathrm{C}_{4} \mathrm{H}_{4} \mathrm{O}_{6}{ }^{2-}$.

Nakayama et al. (2007) examined mercaptocarboxylic acid as a chelating agent. Mercaptocarboxylic acids were intercalated into $\mathrm{Mg}-\mathrm{Al} \mathrm{LDH}$ accompanied by oxidation of mercapto groups to form disulfide. The intercalation compound selectively adsorbed $\mathrm{Hg}^{2+}$ and $\mathrm{Ag}^{+}$, whereas there was almost no adsorption of $\mathrm{Pb}^{2+}$ and $\mathrm{Cu}^{2+}$. Quantitative adsorption of $\mathrm{Hg}^{2+}$ was observed for mercaptosuccinic acid and 3,3'-dithiodipropionic acid intercalated by $\mathrm{LDH}$. The adsorption sites were verified to be disulfide bonds. The selective adsorption of heavy metal ions was due to the effect of a confined field in the interlayer of LDH. Pavlovic et al. (2009) investigated the adsorption of $\mathrm{Cu}^{2+}, \mathrm{Cd}^{2+}$, and $\mathrm{Pb}^{2+}$ by $\mathrm{LDHs}$ intercalated with the chelating agents diethylenetriaminepentaacetate (dtpa) and meso-2,3dimercaptosuccinate (dmsa). $\mathrm{NO}_{3} \bullet \mathrm{Zn}-\mathrm{Al} \mathrm{LDH}$ was intercalated with the chelating agents dtpa and dmsa by anion exchange, and the adsorption of these metal ions occurred mainly 
through chelation by interlayer ligands. The adsorption isotherms indicated a high hostguest affinity. The presence of dmsa in the $\mathrm{Zn}-\mathrm{Al} \mathrm{LDH}$ interlayer increased the affinity for the metal ions relative to dtpa $\bullet \mathrm{Zn}-\mathrm{Al} \mathrm{LDH}$. Although $\mathrm{Cu}^{2+}, \mathrm{Cd}^{2+}$, and $\mathrm{Pb}^{2+}$ were mainly adsorbed by chelation, a certain amount may have been precipitated due to the higher surface alkalinity of the $\mathrm{LDH}$. $\mathrm{PbCO}_{3}$ was also detected. Precipitation of amorphous metal and isomorphous substitution of $\mathrm{Zn}^{2+}$ by another metal ion in the brucite-like layer might also have been involved in the adsorption processes. Liang et al. (2010) also examined the sorption of $\mathrm{Pb}^{2+}$ by $\mathrm{LDH}$ intercalated with dtpa. $\mathrm{Mg}-\mathrm{Al} \mathrm{LDH}$ intercalated with dtpa was prepared by coprecipitation. The maximum adsorption of $\mathrm{Pb}^{2+}$ was about 170 and $40 \mathrm{mg} / \mathrm{g}$ for dtpa $\bullet \mathrm{Mg}-\mathrm{Al} \mathrm{LDH}$ and $\mathrm{Cl} \bullet \mathrm{Mg}-\mathrm{Al} \mathrm{LDH}$, respectively. Langmuir isotherms described the sorption data well, and a pseudo-second-order kinetic model fit the sorption kinetic processes better for both the LDHs. The mechanism of $\mathrm{Pb}^{2+}$ adsorption on dtpa $\bullet \mathrm{Mg}-\mathrm{Al}$ $\mathrm{LDH}$ can be explained by $\mathrm{Pb}-\mathrm{dtpa}$ chelation, while that for $\mathrm{Cl} \bullet \mathrm{Mg}-\mathrm{Al} \mathrm{LDH}$ was primarily surface-induced precipitation.

\section{Uptake of nonionic organic compounds by organically modified LDH}

Recently, LDH and its oxide have been investigated as scavengers to treat wastewater containing anionic organic contaminants. The materials are known to function as effective anion adsorbents in the uptake of phenols, terephthalate, anionic surfactants, ionizable pesticides and herbicides, humic and fulvic acid, anionic dyes, and colored organics from aqueous solutions (Ulibarri et al., 1995; Hermosin et al., 1996; Pavlovic et al., 1997; Barriga et al., 2002; Crepaldi et al., 2002; You et al., 2002a; Orthman et al., 2003; Pavlovic et al., 2005; Li et al., 2005; Cardoso and Valim, 2006; Vreysen and Maes, 2008; Chao et al., 2009; Gaini et al., 2009; Valente et al., 2009; Setti et al., 2010; Sun et al., 2010). Based on the ability of LDH to intercalate various types of anions in interlayers, organic-inorganic composite materials could be produced by intercalation of organic anions having functional groups in their structure into the interlayers of LDH. LDHs modified with organic anions are expected to take up nonionic organic compounds from aqueous solution depending on the functional groups in the structure of the intercalated organic anions. For example, $\mathrm{Mg}-\mathrm{Al} \mathrm{LDH}$ intercalated with dodecylsulfate (DS) could adsorb hydrophobic pesticides such as linuron, atrazine, acephate, and diazinon from aqueous solution (Villa et al., 1999). This is due to the modification of the interlayer surface of the LDH from hydrophilic to hydrophobic. Modification of Mg-Al LDHs with DS and dodecylbenzenesulfonate resulted in very high adsorption of the uncharged pesticide triadimefon (Celis et al., 2000). The high adsorption of triadimefon was due to the paraffin-like sorbents. Dissolution of the hydroxide structure of the LDHs at low $\mathrm{pH}(<4)$ limited their use as sorbents in acidic conditions. For interlayer adsorption of triadimefon in LDHs, X-ray diffraction (XRD) and Fourier transform infrared (FT-IR) studies indicated weak interactions between the pesticide molecules and the sorbents, in agreement with the high reversibility observed in the adsorption-desorption isotherms. You et al. (2002b) examined the surfactant-enhanced adsorption of organic compounds by $\mathrm{Mg}-\mathrm{Al} \mathrm{LDHs}$. Organo-Mg-Al LDHs were prepared by incorporating anionic surfactants, octylsulfate, DS, 4-octylbenzenesulfonate, and dodecylbenzenesulfonate, into $\mathrm{Mg}-\mathrm{Al} \mathrm{LDH}$ via ion exchange. The anionic surfactants were intercalated into $\mathrm{Mg}-\mathrm{Al} \mathrm{LDH}$ with the surfactants oriented perpendicular in the interlayer. The octylsulfate formed bimolecular films, and other surfactants resulted in monolayer structures. Intercalation of 
surfactants into Mg-Al LDH decreased the surface area, whereas surfactants dramatically enhanced the LDH affinity for 1,2,4-trichlorobenzene and 1,1,1-trichloroethane in aqueous solutions. Adsorption potential depended on the type of surfactant as well as the configuration of surfactant molecules within $\mathrm{Mg}-\mathrm{Al} \mathrm{LDH}$ interlayers. The adsorption characteristics indicated that the retention of organic compounds by organo-Mg-Al LDHs was due to a partitioning mechanism. Zhao and Nagy (2004) investigated DS $\bullet \mathrm{Mg}-\mathrm{Al}$ LDHs with a $\mathrm{Mg} / \mathrm{Al}$ molar ratio of 2-5 for trapping chlorinated organic pollutants in water. Adsorption of trichloroethylene and tetrachloroethylene by DS $\bullet \mathrm{Mg}-\mathrm{Al} \mathrm{LDH}$ did not follow a simple trend with increasing organic content but rather varied with probable DS configuration and $\mathrm{LDH}$ composition. $\mathrm{DS} \bullet \mathrm{Mg}-\mathrm{Al} \mathrm{LDH}$ with a $\mathrm{Mg} / \mathrm{Al}$ molar ratio of 3 had the highest affinity for both hydrophobic organic compounds in water because it has the optimal charge density for forming an effective partition medium with the LDH interlayer. $\mathrm{DS} \bullet \mathrm{Mg}-\mathrm{Al} \mathrm{LDH}$ with a $\mathrm{Mg} / \mathrm{Al}$ molar ratio of 2 had the lowest sorption affinity, although it contained the highest amount of DS, and adsorption is thought to occur on edge/external surface area. Wang et al. (2005) examined the surface modification of Mg-Al LDH and incorporation of hydrophobic organic compounds. Surface properties of $\mathrm{Mg}-\mathrm{Al} \mathrm{LDHs}$ intercalated with DS and dodecylbenzenesulfonate were modified from hydrophilic to hydrophobic. Both Mg-Al LDHs adsorbed the nonionic hydrophobic organic pesticide, chlorpyrifos, which was successfully retained in the hydrophobic region of both $\mathrm{Mg}-\mathrm{Al}$ LDHs. Chuang et al. (2008) examined the removal of 2-chlorophenol from aqueous solution by $\mathrm{NO}_{3} \bullet \mathrm{Mg}-\mathrm{Al} \mathrm{LDH}$ and $\mathrm{DS} \bullet \mathrm{Mg}-\mathrm{Al} \mathrm{LDH}$. The dissociation of 2-chlorophenol was 8.56. A high concentration of 2-chlorophenol was adsorbed by the hydrophilic-hydrophilic physical interaction of $\mathrm{NO}_{3} \bullet \mathrm{Mg}-\mathrm{Al} \mathrm{LDH}$ when the $\mathrm{pH}$ was >8.56; however, the hydrophobichydrophobic partition interaction of $\mathrm{DS} \bullet \mathrm{Mg}-\mathrm{Al} \mathrm{LDH}$ was more important when the $\mathrm{pH}$ was $<8.56$. The efficiencies of both LDHs with respect to the enhancement of 2-chlorophenol adsorption are strongly dependent on $\mathrm{pH}$, speciation, ionic strength, and metal dissolution. As mentioned above, organo LDH has the potential to take up nonionic organic contaminants from an aqueous solution. We studied the preparation of organo-Mg-Al LDH and its uptake of bisphenol A. Furthermore, we studied the selective uptake of nonionic organic contaminants from aqueous solution. These studies are discussed in the following sections.

\subsection{Nonselective uptake of aromatic compounds}

Recently, the contamination of effluents and water in our environment with hazardous organic materials has become more serious, and a great deal of effort has been made to develop water-cleaning technology and materials usable for this purpose. It is generally known that toxic organic contaminants, including PCB (polychlorinated biphenyls), dioxin, fran, and other so-called endocrine disruptors and organic halides have low solubility in water. For effective elimination of toxic organic materials from aqueous environments, the development of an adsorbent or absorbent for these materials at fairly low concentrations is an urgent requisite. Some types of oils are candidates for the role of scavengers. Sufficiently frequent contact of the contaminants with these oils will require an energy-intensive process and dispersion of oil droplets of adequately small size coupled with oil-water phase separation. To overcome these challenges, the primary objective of this series of studies was to investigate the use of solid particles modified with organic materials that perform the 
function of picking up the target organic contaminant. Solids of this type are expected to enable handling of the solid particles housing the oily and viscous organic materials and even the water-soluble materials in their structure. The first attempt was the formation of LDH particles holding an organic substance with the desired function in their interlayers. When anionic organic acid species are intercalated into the interlayers of $\mathrm{LDH}$, they remain functional; the chemically modified $\mathrm{LDH}$ can be an effective scavenger for organic contaminants in aqueous effluents.

We prepared $\mathrm{DS} \cdot \mathrm{Mg}-\mathrm{Al} \mathrm{LDH}$ with a $\mathrm{Mg} / \mathrm{Al}$ molar ratio of 3 by adding a solution of $\mathrm{Mg}\left(\mathrm{NO}_{3}\right)_{2}$ and $\mathrm{Al}\left(\mathrm{NO}_{3}\right)_{3}$ to an aqueous solution of DS at a constant $\mathrm{pH}$ of 10.0 (Kameda et al., 2005b). The intercalation of DS- into Mg-Al LDH was controlled primarily by the charge balance between the positive electric charge of Al-bearing brucite-like octahedral layers and the anion in the interlayer. The capacity of DS• $\mathrm{Mg}-\mathrm{Al} \mathrm{LDHs}$ and $\mathrm{CO}_{3} \bullet \mathrm{Mg}-\mathrm{Al} \mathrm{LDH}$ to take up bisphenol A from an aqueous solution was examined by suspending 100-mg samples in $20 \mathrm{~mL}$ of $100 \mathrm{mg} / \mathrm{L}$ bisphenol A solution under shaking at $20{ }^{\circ} \mathrm{C}$ for $10 \sim 360 \mathrm{~min}$. For $\mathrm{DS} \bullet \mathrm{Mg}-\mathrm{Al} \mathrm{LDHs}$ with a DS/Al molar ratio of 1.0, the concentration of bisphenol A decreased very rapidly to $15 \mathrm{mg} / \mathrm{L}$ within $30 \mathrm{~min}$. For DS $\bullet \mathrm{Mg}-\mathrm{Al} \mathrm{LDH}$ with a DS/ Al molar ratio of 0.5 , the concentration of bisphenol A decreased to $50 \mathrm{mg} / \mathrm{L}$ within $30 \mathrm{~min}$. However, for $\mathrm{CO}_{3} \bullet \mathrm{Mg}-\mathrm{Al} \mathrm{LDH}$ with no DS content, only a slight decrease in the concentration of bisphenol A was observed. These results indicate that DS- in the interlayer gives rise to the uptake of bisphenol A from the aqueous solution into the chemically modified $\mathrm{Mg}-\mathrm{Al} \mathrm{LDH}$, probably caused by the hydrophobic interactions between the DS- and bisphenol A. The organic material DS maintained adequate functionality in the interlayer of DS•Mg-Al LDH and can be handled as a fine powder with hydrophobic properties. In the XRD patterns of $\mathrm{DS} \bullet \mathrm{Mg}-\mathrm{Al} \mathrm{LDH}$ before and after the uptake of bisphenol A, no detectable change was observed. This implies that the basal spacing of $\mathrm{DS} \bullet \mathrm{Mg}-\mathrm{Al} \mathrm{LDH}$ was not affected by the uptake of bisphenol A, i.e., bisphenol A did not cause the interlayer to expand by being incorporated into the space between the intercalated DS- and $\mathrm{Mg}(\mathrm{OH})_{2}$-type host lattice. Bisphenol A is thought to be incorporated into the openings between the alkyl groups of DSin the interlayer of $\mathrm{DS} \bullet \mathrm{Mg}-\mathrm{Al} \mathrm{LDH}$; this space is approximately $22 \AA$. It is generally accepted that the large interlayer space, occupied by organic anions, accommodates organic compounds of long molecular lengths, such as bisphenol A. The extraction of bisphenol A taken-up by $\mathrm{DS} \bullet \mathrm{Mg}-\mathrm{Al} \mathrm{LDH}$ with a DS/Al molar ratio of 1.0 has been attempted using ethanol. In the extraction with deionized water free of ethanol, the concentration of bisphenol A was $16.8 \mathrm{mg} / \mathrm{L}$, corresponding to extraction of less than $5 \%$ of the bisphenol A uptaken by $\mathrm{DS} \bullet \mathrm{Mg}-\mathrm{Al} \mathrm{LDH}$; extraction of bisphenol $\mathrm{A}$ with water was minimal. The concentration of bisphenol $\mathrm{A}$ in the extraction media increased sharply with increasing ethanol concentration and was as high as $320 \mathrm{mg} / \mathrm{L}$ for $99.5 \%$ ethanol solution. This observed value is equivalent to approximately $90 \%$ of the bisphenol A taken-up by DS•MgAl LDH. The bisphenol A taken-up by DS $\bullet \mathrm{Mg}-\mathrm{Al}$ LDH was easily extracted with ethanol. This extraction was attributed to the hydrophobic interactions between ethyl groups of ethanol and methyl groups of bisphenol $\mathrm{A}$ as well as hydrogen bonds formed by hydroxyl groups of the two compounds. The DS- intercalated in the interlayer of DS•Mg-Al LDH was not dissolved by ethanol solution. To confirm the stable intercalation of DS- in the interlayer after extraction, the uptake capacity of ethanol-treated $\mathrm{DS} \bullet \mathrm{Mg}-\mathrm{Al} \mathrm{LDH}$ for bisphenol $\mathrm{A}$ in an aqueous solution was compared with that of fresh $\mathrm{DS} \bullet \mathrm{Mg}-\mathrm{Al} \mathrm{LDH}$. In 
the presence of a suspension of ethanol-treated $\mathrm{DS} \bullet \mathrm{Mg}-\mathrm{Al} \mathrm{LDH}$, the concentration of bisphenol A decreased from $100 \mathrm{mg} / \mathrm{L}$ to $11.9 \mathrm{mg} / \mathrm{L}$, similar to that for fresh $\mathrm{DS} \bullet \mathrm{Mg}-\mathrm{Al}$ $\mathrm{LDH}(10.9 \mathrm{mg} / \mathrm{L})$. This result proves that $\mathrm{DS} \bullet \mathrm{Mg}-\mathrm{Al} \mathrm{LDH}$ was regenerated by the extraction of bisphenol A with ethanol, i.e., the intercalated DS- remained in the interlayer. DS- was rigidly fixed in the interlayer, in contact with ethanol as well as bisphenol A solution. To summarize, it was confirmed that $\mathrm{DS} \bullet \mathrm{Mg}-\mathrm{Al} \mathrm{LDH}$ retains its activity during repeated cycles of uptake and extraction of bisphenol A. The DS- in the solid particles was in a stable arrangement in the solid phase while simultaneously reacting rapidly with bisphenol A outside the particles.

We examined the preparation and characterization of $\mathrm{Mg}-\mathrm{Al} \mathrm{LDHs}$ intercalated with 2naphthalene sulphonate (2-NS-) and 2,6-naphthalene disulphonate (2,6-NDS2-) (Kameda et al., 2006). 2-NS・Mg-Al LDH and 2,6-NDS•Mg-Al LDH, with 2-NS- or 2,6-NDS2intercalated in the interlayer of $\mathrm{Mg}-\mathrm{Al} \mathrm{LDH}$, were prepared by dropwise addition of a mixed aqueous solution of $\mathrm{Mg}\left(\mathrm{NO}_{3}\right)_{2}$ and $\mathrm{Al}\left(\mathrm{NO}_{3}\right)_{3}$ at a $\mathrm{Mg} / \mathrm{Al}$ molar ratio of 3.0 to an aqueous ethanol solution of 2-NS-Na or to an aqueous solution of 2,6-NDS-Na $\mathrm{Na}_{2}$ at a constant $\mathrm{pH}$ of 10.0 and left standing at $30{ }^{\circ} \mathrm{C}$ for $1 \mathrm{~h}$. The intercalated 2-NS- and 2,6-NDS2maintained their intrinsic molecular structure in the interlayer of $\mathrm{Mg}-\mathrm{Al} \mathrm{LDH}$. XRD analysis confirmed that 2-NS $\bullet \mathrm{Mg}-\mathrm{Al} \mathrm{LDH}$ had two basal spacings of approximately 19 and $9 \AA$. It is likely that 2-NS- was intercalated in the interlayer of $\mathrm{Mg}-\mathrm{Al} \mathrm{LDH}$ in two orientations. It is believed that the naphthalene ring of 2-NS- was oriented parallel and perpendicular to the brucite $\left(\mathrm{Mg}(\mathrm{OH})_{2}\right)$-like layers of $\mathrm{Mg}-\mathrm{Al} \mathrm{LDH}$. The 2-NS/ $\mathrm{Al}$ molar ratio in the 2-NS $\bullet \mathrm{Mg}-\mathrm{Al}$ $\mathrm{LDH}$ increased with increasing 2-NS/ Al molar ratio in solution, and the interlayer of $\mathrm{Mg}-\mathrm{Al}$ LDH was intercalated with 2-NS- to near full capacity for neutralization of the positive charge of the host lattice at a 2-NS/ Al molar ratio of 2.0 in solution. The XRD patterns of 2,6$\mathrm{NDS} \bullet \mathrm{Mg}-\mathrm{Al} \mathrm{LDH}$ exhibited very weak, broad peaks corresponding to the basal spacings at $2 \theta$ ranging from $6-11^{\circ}$, suggesting an irregular arrangement of $2,6-\mathrm{NDS}^{2-}$ in the $\mathrm{Mg}-\mathrm{Al} \mathrm{LDH}$ interlayers. This was attributed to the limited mobility of the 2,6-NDS2- resulting from the pin-up of the anions at the two $-\mathrm{SO}_{3}{ }^{-}$groups on either side of the interlayer. In contrast to 2$\mathrm{NS}^{-}$, the intercalation with 2,6-NDS2- was approximately $80 \%$ of the value expected due to the charge balance on the $\mathrm{Mg}-\mathrm{Al} \mathrm{LDH}$. The disordered configuration of 2,6-NDS2- in the interlayer of $\mathrm{Mg}-\mathrm{Al} \mathrm{LDH}$ was presumed to restrict the intercalation.

We also investigated the properties of $2-\mathrm{NS} \bullet \mathrm{Mg}-\mathrm{Al} \mathrm{LDH}$ and $2,6-\mathrm{NDS} \bullet \mathrm{Mg}-\mathrm{Al} \mathrm{LDH}$ as scavengers for organic contaminants having aromatic rings in their molecular structures (Kameda et al., 2007). The ability of 2-NS $\bullet \mathrm{Mg}-\mathrm{Al} \mathrm{LDH}$ and 2,6-NDS $\bullet \mathrm{Mg}-\mathrm{Al} \mathrm{LDH}$ to take up bisphenol A from aqueous solution was examined by suspending $0.1 \mathrm{~g}$ of the samples in 20 $\mathrm{mL}$ of $100 \mathrm{mg} / \mathrm{L}$ bisphenol A solution while shaking at $20^{\circ} \mathrm{C}$ for $10-360 \mathrm{~min}$. Figure 4 shows the variation in the concentration of bisphenol A with time for 2-NS・Mg-Al LDHs and for $\mathrm{CO}_{3} \bullet \mathrm{Mg}-\mathrm{Al} \mathrm{LDH}$ as a reference material.

For 2-NS $\bullet \mathrm{Mg}-\mathrm{Al} \mathrm{LDHs}$, the concentration of residual bisphenol A decreased very rapidly from $100 \mathrm{mg} / \mathrm{L}$ to $10 \mathrm{mg} / \mathrm{L}$ or less in the first $30 \mathrm{~min}$ and then decreased fairly slowly. In particular, at a $2-\mathrm{NS} / \mathrm{Al}$ of 0.43 , the lowest molar ratio, the concentration decreased to less than $3 \mathrm{mg} / \mathrm{L}$ within $30 \mathrm{~min}$. In contrast, for $\mathrm{CO}_{3} \bullet \mathrm{Mg}-\mathrm{Al} \mathrm{LDH}$ without chemical modification of the interlayer, only a slight decrease in the bisphenol A concentration was observed. These results demonstrate that the adsorption of bisphenol A on the LDH particles plays a minor role and that the intercalated organic entity may be largely responsible for the uptake of bisphenol A from aqueous solution. The uptake of bisphenol A from aqueous solution was attributed to the association of the naphthalene rings of the 2- 
NS- with the benzene rings of the incorporated bisphenol A. 2,6-NDS • Mg-Al LDH also had the potential to take up bisphenol A from aqueous solution. The intrinsic functions of the naphthalene ring of 2,6-NDS2- were unchanged in the interlayer and positively affected the uptake of bisphenol A due to the association between the aromatic rings. $\mathrm{Mg}-\mathrm{Al} \mathrm{LDH}$ with lower contents of 2-NS- or 2,6-NDS2- in the interlayer had larger potential to take up bisphenol A from aqueous solution than that with more intercalated organic acid. The former is thought to have larger spaces to accommodate more bisphenol $\mathrm{A}$ in the interlayer than the latter, which had limited space due to the higher content of the intercalated entity. It is expected that practical water-cleaning processes should be able to continuously treat wastewater contaminated with hazardous organic compounds at an acceptable flow rate. This can be achieved by passing wastewater through a column containing absorbents. In our study, the test solutions containing bisphenol A and ethanol were alternately passed through a DS $\bullet \mathrm{Mg}-\mathrm{Al} \mathrm{LDH}$ particle column (length $=48 \mathrm{~mm}$, inner diameter $=4.6 \mathrm{~mm}$ ) to examine the cycles of uptake of bisphenol A and elution of uptaken bisphenol A by ethanol (Kameda et al., 2009c). The test solution containing bisphenol A, ethanol, or deionized water was passed through the column at a rate of $1.5 \mathrm{~mL} / \mathrm{min}$ at 80 psi using a gradient pump according to the designed pattern of flow. The column packed with fine particles of the adsorbent produced a high pressure drop, and a high operation pressure was applied to maintain the desired flow rates. The volume of the column was $0.8 \mathrm{~mL}$, and the space velocity was calculated to be $112.5 \mathrm{~h}^{-1}$ under the conditions used in this study. The column was filled with $0.5 \mathrm{~g}$ of $\mathrm{DS} \bullet \mathrm{Mg}-\mathrm{Al} \mathrm{LDH}$ particles and maintained at $20{ }^{\circ} \mathrm{C}$ using a water bath. Metal filters with pore diameters of 2.0 and $0.5 \mu \mathrm{m}$ were placed at the top and bottom of the column to hold the particles. Residual bisphenol A in the effluent from the column was continuously monitored at a wavelength of $280 \mathrm{~nm}$ using a photomultiplier detector. First, deionized water was passed through the column for $10 \mathrm{~min}$ to clean the column and to monitor the system. Then, bisphenol A solution was fed to the column. Figure 5 presents the variation in the absorbance $(\lambda=280 \mathrm{~nm})$ observed using the photomultiplier detector for a flow of $100 \mathrm{mg} / \mathrm{L}$ bisphenol A solution without the column and that for the effluent from the column containing DS•Mg-Al LDH particles.

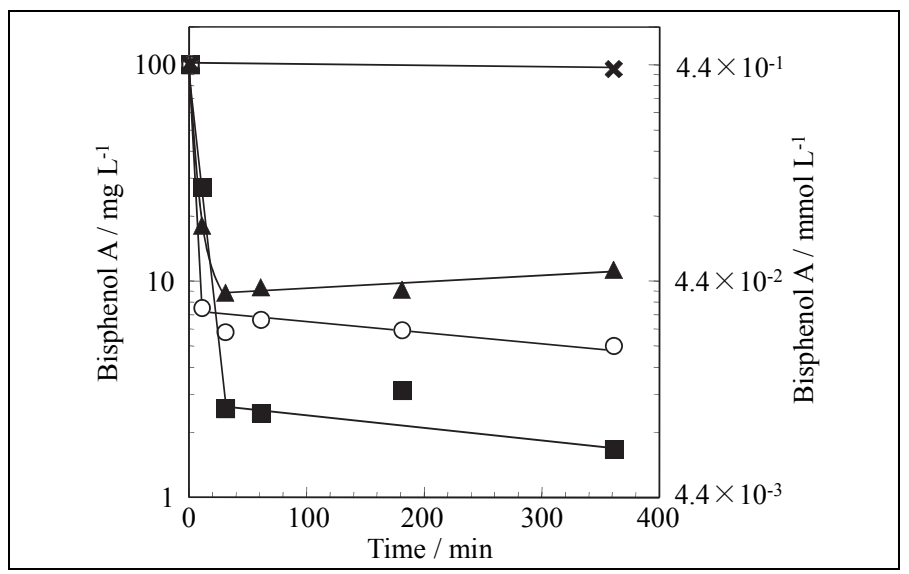

Fig. 4. Variation in the concentration of bisphenol A with time for suspensions of $2-\mathrm{NS} \bullet \mathrm{Mg}-$ $\mathrm{Al} \mathrm{LDH}$ and $\mathrm{CO}_{3} \bullet \mathrm{Mg}-\mathrm{Al} \mathrm{LDH}$ in bisphenol A solution. 2-NS $\bullet \mathrm{Mg}-\mathrm{Al} \mathrm{LDH}$ : the 2-NS/ $\mathrm{Al}$ molar ratio was $0.43(\mathbf{\bullet}), 0.82(\circ)$, and $0.96(\mathbf{\Delta}) \mathrm{CO}_{3} \bullet \mathrm{Mg}-\mathrm{Al} \mathrm{LDH:} \mathrm{(×)}$ 
In the absence of the column (Fig. 5(a)), no absorbance was detected during the first $10 \mathrm{~min}$ of deionized water flow. The line corresponding to the first $10 \mathrm{~min}$ in Fig. 5(a) is hereafter referred to as the baseline. Immediately after the flow of bisphenol A solution, the absorbance quickly increased to a value corresponding to the concentration of bisphenol A and remained constant. This proves that the bisphenol $\mathrm{A}$ in aqueous solution was continuously monitored with high sensitivity by the detector. When deionized water was passed through the column containing DS•Mg-Al LDH particles (Fig. 5(b)) for $10 \mathrm{~min}$, the absorbance rapidly increased and immediately decreased to the baseline. The rapid increase in the absorbance may be attributable to the dissociation of molecular sodium dodecylsulfate (SDS) dissolved in the intercalated DS- medium in DS•Mg-Al LDH due to hydrophobic interactions. As a result, the $\mathrm{DS} \bullet \mathrm{Mg}-\mathrm{Al} \mathrm{LDH}$ particles in the column required an initial washing with water to remove SDS from the LDH. After the first 10 min (Fig. 5(b)), when bisphenol A was passed through the column, the measured absorbance remained on the baseline for $200 \mathrm{~min}$, i.e., the concentration of bisphenol $\mathrm{A}$ in the effluent was less than the detection limit of the detector used in this study $(0.1 \mathrm{mg} / \mathrm{L})$. This elimination of bisphenol A was observed for the effluent with a volume 356 times that of the column. This suggests that bisphenol A was taken up by the DS•Mg-Al LDH particles during its flow through the column. However, the absorbance gradually increased after $200 \mathrm{~min}$, indicating the presence of bisphenol $\mathrm{A}$ in the effluent. This reflects the gradual decrease in the accommodation space for bisphenol $\mathrm{A}$ in the interlayers of DS $\bullet \mathrm{Mg}-\mathrm{Al} \mathrm{LDH}$ with time, approaching a break-through point, $260 \mathrm{~min}$, at which the concentration reached $10 \mathrm{mg} / \mathrm{L}$. The column has the potential to be used for the treatment of bisphenol A solution for 260 min under the conditions used in this study. Due to the flow of bisphenol A solution through the column, the $\mathrm{pH}$ of the effluent increased immediately from an initial value of 5.2 to near 7.0 and then remained in the range of $6.0-8.0$. The $\mathrm{Mg}^{2+}$ concentrations were very low at each stage. These results are acceptable according to the water quality standard in Japan ( $5<\mathrm{pH}<9 ; \mathrm{Mg}^{2+}$ is not listed there). From the XRD analysis, it can be deduced that the configuration of the intercalated DS- in DS $\bullet \mathrm{Mg}-\mathrm{Al} \mathrm{LDH}$ was not affected by the flow of bisphenol A solution.

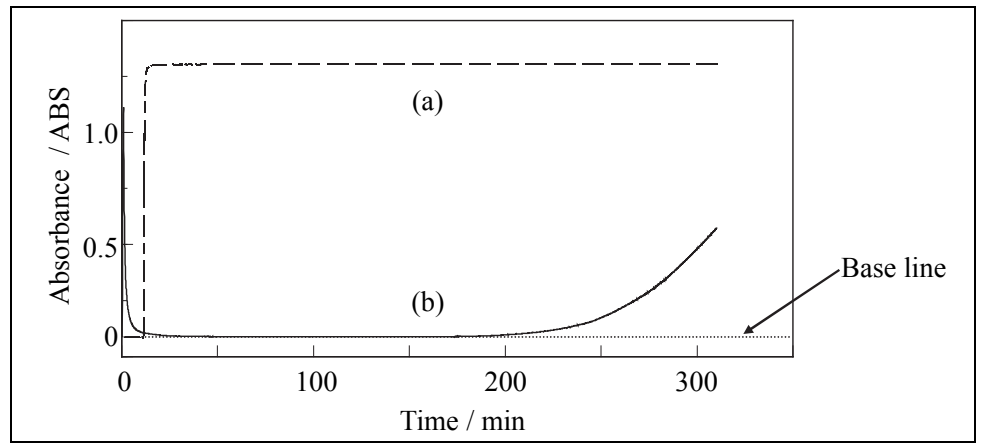

Fig. 5. Variation in absorbance $(\lambda=280 \mathrm{~nm})$ observed using a photomultiplier detector for (a) flow of $100 \mathrm{mg} / \mathrm{L}$ bisphenol A solution without a column and (b) effluent from a column containing $\mathrm{DS} \bullet \mathrm{Mg}-\mathrm{Al} \mathrm{LDH}$ particles.

Furthermore, bisphenol A solution and ethanol were alternately passed through a column containing $\mathrm{DS} \bullet \mathrm{Mg}-\mathrm{Al} \mathrm{LDH}$ particles to investigate the possibility of continuous treatment, consisting of repeated cycles of bisphenol A uptake from the aqueous solution and ethanol 
elution of the uptaken bisphenol A. The designed pattern of the alternate flow of bisphenol A solution and ethanol is presented in Fig. 6 (A). This figure represents a flow series of deionized water for $0-10 \mathrm{~min}, 100 \mathrm{mg} / \mathrm{L}$ bisphenol A solution for 10-40 min, deionized water for 40-45 $\mathrm{min}$, and ethanol solution for 45-60 min to elute bisphenol A from the DSlayer. In the ethanol elution stage, the ethanol concentration increased to $50 \mathrm{vol} \%$ at 10 $\mathrm{vol} \% / \mathrm{min}$ during the first $5 \mathrm{~min}$ and remained constant at $50 \mathrm{vol} \%$ for the following $5 \mathrm{~min}$.

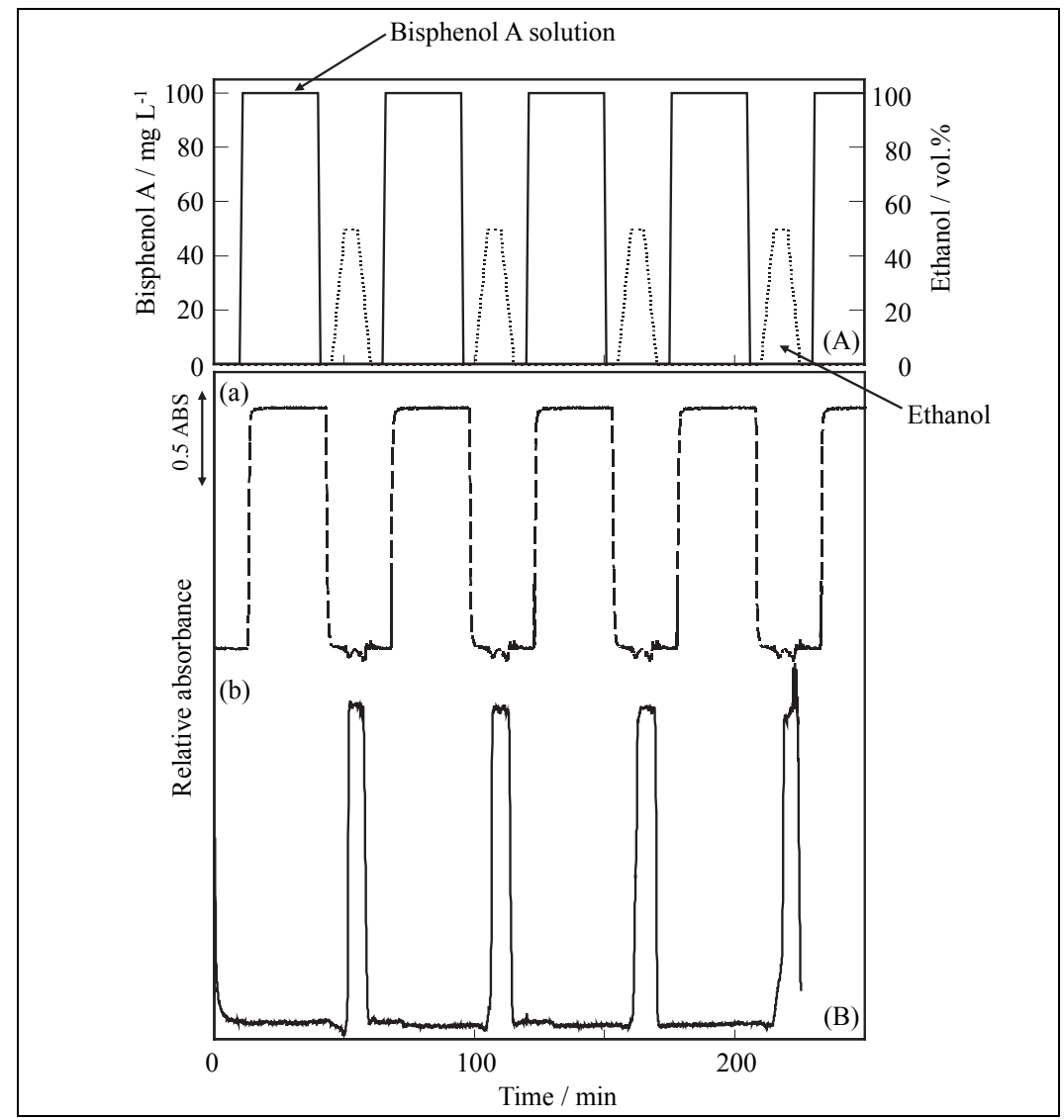

Fig. 6. (A) Designed pattern for alternate flow of bisphenol A solution and ethanol with a flow rate of $1.5 \mathrm{~mL} / \mathrm{min}$. (B) Variation in the absorbance $(\lambda=280 \mathrm{~nm})$ of the effluent obtained by alternate flow of bisphenol A solution and ethanol (a) without a column and (b) through a column containing $\mathrm{DS} \bullet \mathrm{Mg}-\mathrm{Al} \mathrm{LDH}$ particles.

Then, for the last $5 \mathrm{~min}$, the concentration decreased to $0 \mathrm{vol} \%$ at a constant rate of 10 $\mathrm{vol} \% / \mathrm{min}$. After the flow of deionized water for $60-65 \mathrm{~min}, 100 \mathrm{mg} / \mathrm{L}$ bisphenol A solution was passed through the column again, and this cycle was repeated. Figure 6 (B) presents the variation in the absorbance $(\lambda=280 \mathrm{~nm})$ for the effluent from the column by the alternate flow of bisphenol A and ethanol solutions and the corresponding curve for the system without the column. For the system without the column (Fig. 6 (B)(a)), a constant absorbance 
was obtained for the flow of bisphenol A solution, while no absorbance was detected for the flow of deionized water and ethanol. The variation in the absorbance corresponds well to the flow conditions presented in Fig. 6 (A). For the system with a column containing DS $\bullet \mathrm{Mg}-\mathrm{Al} \mathrm{LDH}$ particles (Fig. 6 (B)(b)), no absorbance was detected during the flow of bisphenol A solution through the column, indicating that bisphenol A was almost completely eliminated by the $\mathrm{DS} \bullet \mathrm{Mg}-\mathrm{Al} \mathrm{LDH}$ particles. In contrast, the absorbance increased with the flow of ethanol solution, confirming that bisphenol A taken-up by the $\mathrm{DS} \bullet \mathrm{Mg}-\mathrm{Al} \mathrm{LDH}$ particles was eluted by ethanol. The maximum concentration of bisphenol A in ethanol was $130 \mathrm{mg} / \mathrm{L}$, which was higher than the concentration $(100 \mathrm{mg} / \mathrm{L})$ of bisphenol A solution, indicating that the bisphenol A was concentrated to $130 \%$ under the conditions in this study. These results show that bisphenol A could be continuously eliminated by DS $\bullet \mathrm{Mg}-\mathrm{Al} \mathrm{LDH}$, which can be regenerated through ethanol elution. This suggests that the uptake of bisphenol A from the aqueous phase and its elution from the DSlayer in the $\mathrm{LDH}$ are qualitative and fairly quick processes. The absorbance measurement was performed over $224 \mathrm{~min}$ of flow, as presented in Fig. 6 (B)(b), and ceased due to the increase in pressure inside the column. This may be attributable to the swelling of the $\mathrm{DS} \bullet \mathrm{Mg}-\mathrm{Al} \mathrm{LDH}$ particles caused by the incorporation of ethanol in the interlayers of the $\mathrm{LDH}$. To summarize, the DS•Mg-Al LDH particles packed in a column were found to continuously take up bisphenol A from the aqueous solution. Furthermore, they were regenerated by elution of the uptaken bisphenol A by ethanol. The column containing $\mathrm{DS} \bullet \mathrm{Mg}-\mathrm{Al} \mathrm{LDH}$ particles is expected to be applicable for the treatment of wastewater containing organic substances. According to the results of this study, the composite materials coupling LDH with organic anions are expected to be effective absorbents for organic as well as inorganic contaminants in aqueous solution. By such a technique, watersoluble or intrinsically liquid materials can be applied to water-cleaning processes based on column-style operations.

\subsection{Selective uptake of aromatic compounds}

In environmental systems, hazardous organic contaminants can coexist with natural organic materials in wastewater effluents. If $\mathrm{Mg}-\mathrm{Al} \mathrm{LDHs}$ intercalated with organic anions selectively take up target organic materials from wastewater streams, they may be useful as effective scavengers for water treatment. To take up target organic materials selectively, the electronic state of the intercalated aromatic anions can be manipulated by the addition of electron-donating or -withdrawing substituents, thereby activating or deactivating the aromatic rings, respectively. Activated and deactivated systems interact strongly, generating a $\Pi-\Pi$ stacked geometry (Gung and Amicangelo, 2006). Mg-Al LDHs intercalated with aromatic anions are thus expected to selectively take up hazardous aromatic compounds from wastewater due to the strong electrostatic attraction between the aromatic rings of $\mathrm{Mg}$ Al LDHs and those of the hazardous aromatics.

We investigated the selective uptake of six aromatic compounds with different functional groups from aqueous solutions by $\mathrm{Mg}-\mathrm{Al} \mathrm{LDH}$ intercalated with 2,7-naphthalene disulfonate (2,7-NDS2-) (Kameda et al., 2009d, 2009e). The six examined compounds were 1,3-dinitrobenzene (DNB), nitrobenzene (NB), benzaldehyde (BA), anisole (AS), N,Ndimethylaniline (DMA), and 1,2-dimethoxybenzene (DMB). 2,7-NDS $\bullet \mathrm{Mg}-\mathrm{Al} \mathrm{LDH}$ (Mg/ $\mathrm{Al}$ $=2.9 ; 2,7-\mathrm{NDS} / \mathrm{Al}=0.31$ ) was added to $20 \mathrm{~mL}$ of a single solution consisting of each aromatic compound at a concentration of $0.5 \mathrm{mM}$, and it was shaken at $20^{\circ} \mathrm{C}$ for $120 \mathrm{~min}$. In 
this case, the amount of $2,7-\mathrm{NDS} \bullet \mathrm{Mg}-\mathrm{Al} \mathrm{LDH}$ added was such that the molar ratio of intercalated 2,7-NDS2- to each compound was 50. To demonstrate the effect of the interlayer anions on the uptake of aromatics, $\mathrm{DS} \bullet \mathrm{Mg}-\mathrm{Al} \mathrm{LDH}(\mathrm{Mg} / \mathrm{Al}=3.2 ; \mathrm{DS} / \mathrm{Al}=0.98)$ and $\mathrm{CO}_{3} \bullet \mathrm{Mg}-\mathrm{Al} \mathrm{LDH}$ were also used as reference materials. When DS $\bullet \mathrm{Mg}-\mathrm{Al} \mathrm{LDH}$ was added to the single solution, the molar ratio of intercalated DS- to each compound was 50 . The amount of $\mathrm{CO}_{3} \bullet \mathrm{Mg}-\mathrm{Al} \mathrm{LDH}$ was $0.5 \mathrm{~g}$. Table 1 shows the uptake of each aromatic compound from the single solution by $2,7-\mathrm{NDS} \bullet \mathrm{Mg}-\mathrm{Al} \mathrm{LDH}, \mathrm{DS} \bullet \mathrm{Mg}-\mathrm{Al} \mathrm{LDH}$, and $\mathrm{CO}_{3} \bullet \mathrm{Mg}-\mathrm{Al} \mathrm{LDH}$.

\begin{tabular}{lcccccc|}
\hline \multirow{2}{*}{ Mg-Al LDH } & \multicolumn{6}{c|}{ Uptake (\%) } \\
\cline { 2 - 7 } & DNB & \multicolumn{1}{c|}{ NB } & \multicolumn{1}{c|}{ BA } & AS & DMA & DMB \\
\hline $2,7-$ NDS $^{2-}$ & 84.7 & 56.5 & 46.4 & 28.3 & 20.4 & 14.2 \\
DS- $^{-}$ & 56.0 & 61.9 & 41.5 & 66.9 & 75.0 & 62.8 \\
$\mathrm{CO}_{3}^{2-}$ & 0 & 5.7 & 5.1 & 10.5 & 13.3 & 0 \\
\hline
\end{tabular}

Table 1. Uptake of each aromatic compound from a single solution by 2,7-NDS • Mg-Al $\mathrm{LDH}, \mathrm{DS} \bullet \mathrm{Mg}-\mathrm{Al} \mathrm{LDH}$, and $\mathrm{CO}_{3} \bullet \mathrm{Mg}-\mathrm{Al} \mathrm{LDH}$.

The uptake of each aromatic compound by $2,7-\mathrm{NDS} \bullet \mathrm{Mg}-\mathrm{Al} \mathrm{LDH}$ and $\mathrm{DS} \bullet \mathrm{Mg}-\mathrm{Al} \mathrm{LDH}$ was greater than that by $\mathrm{CO}_{3} \bullet \mathrm{Mg}-\mathrm{Al} \mathrm{LDH}$. In the case of $\mathrm{CO}_{3} \bullet \mathrm{Mg}-\mathrm{Al} \mathrm{LDH}$, in which no chemical modification of the interlayer occurred, the uptake was attributed to the adsorption of the aromatic compounds on the surface of the $\mathrm{CO}_{3} \bullet \mathrm{Mg}-\mathrm{Al} \mathrm{LDH}$ particles. The high uptake by $2,7-\mathrm{NDS} \bullet \mathrm{Mg}-\mathrm{Al} \mathrm{LDHs}$ and $\mathrm{DS} \bullet \mathrm{Mg}-\mathrm{Al} \mathrm{LDH}$ was attributed to the interaction between the aromatic compounds and the 2,7-NDS2- and DS- intercalated in the interlayer of $\mathrm{Mg}-\mathrm{Al} \mathrm{LDH}$, respectively. In the case of $\mathrm{DS} \bullet \mathrm{Mg}-\mathrm{Al} \mathrm{LDH}$, the maximum and minimum uptakes were $75.0 \%$ for DMA and $41.5 \%$ for BA, and the dependence of the uptake on the type of aromatic compound was low. This nonselective uptake was likely due to a hydrophobic interaction between the alkyl groups of DS- intercalated in the interlayer and the benzene ring of the compound in the aqueous solution. For 2,7-NDS• Mg-Al LDH, the uptake decreased in the following order: $\mathrm{DNB}>\mathrm{NB}>\mathrm{BA}>\mathrm{AS}>\mathrm{DMA}>\mathrm{DMB}$. The maximum and minimum uptakes were $84.7 \%$ for $\mathrm{DNB}$ and $14.2 \%$ for $\mathrm{DMB}$, and the dependence of the uptake on the type of aromatic compound was high. This selective uptake was attributed to $\Pi-\Pi$ stacking interactions between the benzene ring of the compound and the naphthalene ring of 2,7-NDS2- intercalated in the interlayer spaces of $\mathrm{Mg}-\mathrm{Al} \mathrm{LDH}$. The uptake is thought to depend on the electronic state of the aromatic compound, which, in turn, depends on the functional group. The electronic states of the benzene rings of $\mathrm{DNB}, \mathrm{NB}$, and $\mathrm{BA}$ are compared as follows. All these compounds contain electron-withdrawing groups, namely, $-\mathrm{NO}_{2}$ and $-\mathrm{CHO}$ groups. The strength of $-\mathrm{NO}_{2}$ is greater than that of $-\mathrm{CHO}$. DNB has two $\mathrm{NO}_{2}$ groups, and, therefore, the benzene ring of DNB has the lowest electron density among the aromatics. Additionally, the benzene ring of NB has a lower electron density than that of BA. Next, the electronic states of the benzene rings of AS, DMA, and DMB are compared. These compounds are grouped for comparison because they all contain electron-donating groups, namely, $-\mathrm{OCH}_{3}$ and $-\mathrm{N}\left(\mathrm{CH}_{3}\right)_{2}$ groups. $\mathrm{DMB}$ has two $-\mathrm{OCH}_{3}$ groups, and, thus, the benzene ring of $\mathrm{DMB}$ has the largest electron density among these aromatics. The strength of the $-\mathrm{N}\left(\mathrm{CH}_{3}\right)_{2}$ group is greater than that of the $-\mathrm{OCH}_{3}$ group. This suggests that the benzene ring of DMA has a larger density of electrons than that of AS. In other words, the density of electrons in the benzene ring in the 
aromatics is expected to decrease in the following order: $\mathrm{DMB}>\mathrm{DMA}>\mathrm{AS}>\mathrm{BA}>\mathrm{NB}>$ DNB. The electronic state of the naphthalene ring of 2,7-NDS2- intercalated into the interlayer of 2,7-NDS $\bullet \mathrm{Mg}-\mathrm{Al} \mathrm{LDH}$ can be described as follows. 2,7-NDS2- has two $-\mathrm{SO}_{3}{ }^{-}$ groups in its structure that are weak electron-withdrawing groups. The naphthalene ring is richer in electrons than the benzene ring is, and, thus, the naphthalene ring of 2,7-NDS2probably has a larger density of electrons due to the weak electron-withdrawing ability of the two $-\mathrm{SO}_{3}{ }^{-}$groups. The high uptake of aromatic compounds in the decreasing order of DNB $>$ NB $>$ BA $>$ AS > DMA > DMB by 2,7-NDS $\bullet$ Mg-Al LDH was caused by $\Pi-\Pi$ stacking interactions between the electron-rich naphthalene ring of 2,7-NDS2- intercalated into the interlayer of 2,7-NDS $\bullet \mathrm{Mg}-\mathrm{Al} \mathrm{LDH}$ and the benzene ring of the aromatics, which has lower electron density, in the decreasing order of DMB $>$ DMA $>$ AS $>$ BA $>$ NB $>$ DNB. That is, the electron-poor benzene ring of aromatics showed strong interactions with the electronrich naphthalene ring of intercalated 2,7-NDS2-, and these interactions resulted in the large uptake of aromatics by 2,7-NDS $\bullet \mathrm{Mg}-\mathrm{Al} \mathrm{LDH}$. Table 2 shows the uptake of multiple aromatic compounds from mixed solutions I and II by 2,7-NDS• Mg-Al LDH. In this case, the mixed solution I contained $0.5 \mathrm{mM} \mathrm{DNB}, \mathrm{BA}$, and DMB. The mixed solution II contained $0.5 \mathrm{mM}$ DNB, NB, BA, AS, and DMB.

\begin{tabular}{|cccccc|}
\hline & \multicolumn{5}{c|}{ Uptake (\%) } \\
\cline { 2 - 6 } & DNB & NB & BA & AS & DMB \\
\hline Mixed solution I & 82.8 & - & 30.2 & - & 3.7 \\
Mixed solution II & 79.3 & 47.5 & 32.2 & 12.0 & 6.6 \\
\hline
\end{tabular}

Table 2. Uptake of multiple aromatic compounds from mixed solutions I and II by 2,7$\mathrm{NDS} \bullet \mathrm{Mg}-\mathrm{Al} \mathrm{LDH}$.

Even for the mixtures, uptake was high; uptake decreased in the order DNB $>(\mathrm{NB})>\mathrm{BA}>$ (AS) > DMB. This order matched that of the uptake from the single solution (Table 1). 2,7$\mathrm{NDS} \bullet \mathrm{Mg}-\mathrm{Al} \mathrm{LDH}$ was found to selectively take up aromatic compounds with electron-poor benzene rings from the mixtures in aqueous solution.

$\mathrm{NTS} \bullet \mathrm{Mg}-\mathrm{Al} \mathrm{LDH}$ and ANDS $\bullet \mathrm{Mg}-\mathrm{Al} \mathrm{LDH}$, which respectively contained 1,3,6naphthalenetrisulfonate (NTS3-) and 3-amino-2,7-naphthalenedisulfonate (ANDS2-) intercalated in the interlayer spaces, were also prepared by a coprecipitation technique (Kameda et al., 2010b). The naphthalene core of NTS3- was likely oriented parallel to the brucite-like host layers of $\mathrm{Mg}-\mathrm{Al} \mathrm{LDH}$, lying at the midpoint of the interlayer space. The naphthalene core of ANDS2- was oriented parallel to the brucite-like layers, at the midpoint of the interlayer space, when ANDS $\bullet \mathrm{Mg}-\mathrm{Al} \mathrm{LDH}$ was prepared from a solution with a low concentration of ANDS2-. When a solution with a high concentration of ANDS2- was used in the preparation, the naphthalene core of ANDS2- was thought to be oriented in an irregular fashion with respect to the brucite-like layers. NTS $\bullet \mathrm{Mg}-\mathrm{Al} \mathrm{LDH}$ and ANDS $\bullet \mathrm{Mg}-\mathrm{Al} \mathrm{LDH}$ were both capable of absorbing large quantities of aromatics from aqueous solution in the decreasing order of DNB $>$ NB $>$ BA $>$ DMA $>$ AS $>$ DMB. The difference in absorption was attributed to differences in the extent of $\Pi-\Pi$ stacking interactions occurring between the benzene rings of the aromatics and the naphthalene core of the intercalated NTS3- and ANDS2-. The uptake of aromatics in these cases probably occurred via insertion of the benzene rings of the aromatics between the naphthalene cores of the intercalated NTS3- and ANDS2- and the brucite-like layers. 
We also examined the effect of intercalated aromatic sulfonates on uptake of aromatic compounds from aqueous solutions by modified Mg-Al LDH (Kameda et al., 2010c). We utilized Mg-Al LDHs modified by intercalation with three aromatic sulfonates: 2,7-NDS2-, benzenesulfonate (BS-), and benzenedisulfonate (BDS2-). BS・Mg-Al LDH and BDS•Mg-Al $\mathrm{LDH}$, which respectively contained BS- and BDS2- intercalated in the interlayer space, were prepared by a coprecipitation technique (Kameda et al., 2008b). The intercalated BS- and BDS2- maintained their intrinsic molecular structures within the Mg-Al LDH interlayers. At low intercalation levels, the benzene ring of $\mathrm{BS}-$ in $\mathrm{BS} \bullet \mathrm{Mg}-\mathrm{Al} \mathrm{LDH}$ was inclined at $30^{\circ}$ relative to the plane of the brucite-like layers of $\mathrm{Mg}-\mathrm{Al} \mathrm{LDH}$. With increasing BS- content, the benzene ring adopted an additional configuration perpendicular to the $\mathrm{Mg}-\mathrm{Al} \mathrm{LDH}$ layers. In BDS-intercalated $\mathrm{Mg}-\mathrm{Al} \mathrm{LDH}$, the benzene ring of BDS2- was tilted at $26^{\circ}$ relative to the plane of the $\mathrm{Mg}-\mathrm{Al} \mathrm{LDH}$ layers. Intercalation levels of BDS2- were smaller than those of BS- despite the greater charge density of BDS2-, which was likely attributable to a greater degree of electrostatic repulsion between intercalated anions. The uptake of DNB was notably high and in the order 2,7-NDS $\bullet \mathrm{Mg}-\mathrm{Al} \mathrm{LDH}>\mathrm{BS} \bullet \mathrm{Mg}-\mathrm{Al} \mathrm{LDH}>\mathrm{BDS} \bullet \mathrm{Mg}-\mathrm{Al} \mathrm{LDH}$. This was definitively attributed to the $\Pi-\Pi$ stacking interactions between the electron-poor benzene ring of DNB and the electron-rich aromatic rings of the intercalated aromatic sulfonates, which have electron density in the order 2,7-NDS ${ }^{2-}>$ BS- > BDS2-. To summarize, the electron-rich aromatic rings of intercalated aromatic sulfonates undergo stronger $\Pi-\Pi$ stacking interactions with the electron-poor benzene ring of DNB. The uptake of AS by 2,7$\mathrm{NDS} \bullet \mathrm{Mg}-\mathrm{Al} \mathrm{LDH}$ and $\mathrm{BS} \bullet \mathrm{Mg}-\mathrm{Al} \mathrm{LDH}$ was considerably lower than that of DNB by the same LDHs. The more electron-rich benzene ring of AS was thought to undergo weak $\Pi-\Pi$ stacking interactions with the electron-rich aromatic rings of intercalated 2,7-NDS2- and BS-. Finally, we examined the effect of the interlayer spacing of $\mathrm{Mg}-\mathrm{Al} \mathrm{LDH}$ on the ability to take up a nonionic organic material (Kameda et al., 2009f). Mg-Al LDHs, intercalated with 1propanesulfonate (PS-), 1-hexanesulfonate (HS-), and 1-dodecanesulfonate (DDS-), were prepared by coprecipitation, yielding $\mathrm{PS} \bullet \mathrm{Mg}-\mathrm{Al} \mathrm{LDH}, \mathrm{HS} \bullet \mathrm{Mg}-\mathrm{Al} \mathrm{LDH}$, and $\mathrm{DDS} \bullet \mathrm{Mg}-\mathrm{Al}$ $\mathrm{LDH}$, respectively. The increase in the alkyl chain lengths of the Mg-Al LDHs (PS- < HS- < DDS-) resulted in the perpendicular orientation of the organic acid anions in the interlayer of $\mathrm{Mg}-\mathrm{Al} \mathrm{LDH}$, which in turn resulted in more organic acid anions being accommodated in the interlayer space. An organic acid anion with a long molecular length was more easily intercalated in the interlayer of $\mathrm{Mg}-\mathrm{Al} \mathrm{LDH}$ than one with a short molecular length. This was attributed to the hydrophobic interaction between the alkyl chains, affecting the intercalation of the organic acid anions. The uptake of $N, N$-dimethylaniline (DMA) by $\mathrm{Mg}-$ $\mathrm{Al}$ LDHs increased in the order PS $\bullet \mathrm{Mg}-\mathrm{Al} \mathrm{LDH}<\mathrm{HS} \bullet \mathrm{Mg}-\mathrm{Al} \mathrm{LDH}<\mathrm{DDS} \bullet \mathrm{Mg}-\mathrm{Al} \mathrm{LDH}$. The uptake was attributed to the hydrophobic interactions between DMA and the intercalated PS-, HS-, and DDS-. Thus, Mg-Al LDH, which has many large interlayer spacings when intercalated with organic acid anions, can take up a large number of DMA molecules from an aqueous solution.

\section{Conclusion}

This chapter summarizes the preparation of organically modified LDH by intercalation of organic anions into the interlayer of LDH and the uptake of heavy metal ions and nonionic organic compounds by the organically modified LDH. In particular, we developed hybrid inorganic-organic composite materials capable of selective uptake of heavy metal ions and nonionic organic compounds from aqueous solution. It is significant that we developed a 
relatively simple method for the preparation of the composite materials. Moreover, it must be emphasized that the utilization of a water-soluble reagent was possible by the incorporation of the reagent into an inorganic compound. The composite materials could remove heavy metal ions and bisphenol A from aqueous solutions with high concentrations to very low concentrations in a short time. These materials are expected to be applied for actual wastewater treatment.

\section{Acknowledgment}

This research was partially supported by the Ministry of Education, Science, Sports, and Culture, Grand-in-Aid for Young Scientists (A), 18681010, 2006-2008.

\section{References}

Allmann, R. (1968). The crystal structure of pyroaurite. Acta Crystallographica, Vol. B24, pp. 972-977.

Barriga, C.; Gaitan, M.; Pavlovic, I.; Ulibarri, M. A.; Hermosin, M. C.; Cornejo, J. (2002). Hydrotalcites as sorbent for 2,4,6-trinitrophenol: influence of the layer composition and interlayer anion. Journal of Materials Chemistry, Vol. 12, pp. 1027-1034.

Cardoso, L. P.; Valim, J. B. (2006). Study of acids herbicides removal by calcined $\mathrm{Mg}-\mathrm{Al}-\mathrm{CO}_{3}-$ LDH. Journal of Physics and Chemistry of Solids, Vol. 67, pp. 987-993.

Cavani, F.; Trifiro, F.; Vaccari, A. (1991). Hydrotalcite-type anionic clays: preparation, properties, and applications. Catalysis Today, Vol. 11, pp. 173-301.

Celis, R.; Koskinen, W. C.; Hermosin, M. C.; Ulibarri, M. A.; Cornejo, J. (2000). Triadimefon interactions with organoclays and organohydrotalcites. Soil Science Society of America journal, Vol. 64, pp. 36-43.

Chaara, D.; Pavlovic, I.; Bruna, F.; Ulibarri, M. A.; Draoui, K.; Barriga, C. (2010). Removal of nitrophenol pesticides from aqueous solutions by layered double hydroxides and their calcined products. Applied Clay Science, Vol. 50, pp. 292-298.

Chao, Y. F.; Lee, J. J.; Wang, S. L. (2009). Preferential adsorption of 2,4dichlorophenoxyacetate from associated binary-solute aqueous systems by $\mathrm{Mg} / \mathrm{Al}-$ $\mathrm{NO}_{3}$ layered double hydroxides with different nitrate orientations. Journal of Hazardous Materials, Vol. 165, pp. 846-852.

Chuang, Y. H.; Tzou, Y. M.; Wang, M. K.; Liu, C. H.; Chiang, P. N. (2008). Removal of 2chlorophenol from aqueous solution by $\mathrm{Mg} / \mathrm{Al}$ layered double hydroxide (LDH) and modified LDH. Industrial E Engineering Chemistry Research, Vol. 47, pp. 38133819.

Crepaldi, E. L.; Tronto, J.; Cardoso, L. P.; Valim, J. B. (2002). Sorption of terephthalate anions by calcined and uncalcined hydrotalcite-like compounds. Colloids and Surfaces A: Physicochemical and Engineering Aspects, Vol. 211, pp. 103-114.

Dousova, B.; Machovic, V.; Kolousek, D.; Kovanda, F.; Dornicak, V. (2003). Sorption of As(V) species from aqueous systems. Water, Air, and Soil Pollution, Vol. 149, pp. 251-267.

Fujii, S.; Sugie, Y.; Kobune, M.; Touno, A.; Touji, J. (1992). Uptakes of $\mathrm{Cu}^{2+}, \mathrm{Pb}^{2+}$ and $\mathrm{Zn}^{2+}$ on synthetic hydrotalcite in aqueous solution. Nippon Kagaku Kaishi, Vol. 1992, pp. 1504-1507. 
Gaini, L. E.; Lakraimi, M.; Sebbar, E.; Meghea, A.; Bakasse, M. (2009). Removal of indigo carmine dye from water to $\mathrm{Mg}-\mathrm{Al}-\mathrm{CO}_{3}$-calcined layered double hydroxides. Journal of Hazardous Materials, Vol. 161, pp.627-632.

Gasser, M. S.; Aly, H. F. (2009). Kinetic and adsorption mechanism of $\mathrm{Cu}(\mathrm{II})$ and $\mathrm{Pb}(\mathrm{II})$ on prepared nanoparticle layered double hydroxide intercalated with EDTA. Colloids and Surfaces A: Physicochemical and Engineering Aspects, Vol. 336, pp. 167-173.

Gillman, G. P. (2006). A simple technology for arsenic removal from drinking water using hydrotalcite. Science of the Total Environment, Vol. 366, pp. 926-931.

Goh, K. H.; Lim, T. T.; Dong, Z. (2008). Application of layered double hydroxides for removal of oxyanions: A review. Water Research, Vol. 42, pp. 1343-1368.

Goswamee, R. L.; Sengupta, P.; Bhattacharyya, K. G.; Dutta, D. K. (1998). Adsorption of $\mathrm{Cr}(\mathrm{VI})$ in layered double hydroxides. Applied Clay Science, Vol. 13, pp. 21-34.

Gung, B. W.; Amicangelo, J. C. (2006). Substituent effects in $\mathrm{C}_{6} \mathrm{~F}_{6}-\mathrm{C}_{6} \mathrm{H}_{5} \mathrm{X}$ stacking interactions. Journal of organic chemistry, Vol. 71, pp. 9261-9270.

Hermosin, M. C.; Pavlovic, I.; Ulibarri, M. A.; Cornejo, J. (1996). Hydrotalcite as sorbent for trinitrophenol: Sorption capacity and mechanism. Water Research, Vol.30, pp. 171177.

Ingram, L.; Taylor, H. F. W. (1967). The crystal structures of sjogrenite and pyroaurite. Mineralogical Magazine, Vol. 36, pp. 465-479.

Kameda, T.; Saito, S.; Umetsu, Y. (2005a). Mg-Al layered double hydroxide intercalated with ethylenediaminetetraacetate anion: Synthesis and application to the uptake of heavy metal ions from an aqueous solution. Separation and Purification Technology, Vol. 47, pp. 20-26.

Kameda, T.; Saito, M.; Umetsu, Y. (2005b). Preparation of a composite material for the uptake of bisphenol A from aqueous solutions, the dodecylsulfate ion-intercalated $\mathrm{Mg}-\mathrm{Al}$ layer-structured double hydroxide particles. Journal of Alloys and Compounds, Vol. 402, pp. 46-52.

Kameda, T.; Saito, M.; Umetsu, Y. (2006). Preparation and characterisation of Mg-Al layered double hydroxides intercalated with 2-naphthalene sulphonate and 2,6naphthalene disulphonate. Materials Transactions, Vol. 47, pp. 923-930.

Kameda, T.; Saito, M.; Umetsu, Y. (2007). Uptake of bisphenol A from aqueous solution by $\mathrm{Mg}$-Al-layered double dydroxides intercalated with 2-naphthalene sulfonate and 2,6-naphthalene disulfonate. Materials Transactions, Vol. 48, pp. 2225-2229.

Kameda, T.; Takeuchi, H.; Yoshioka, T. (2008a). Uptake of heavy metal ions from aqueous solution using Mg-Al layered double hydroxides intercalated with citrate, malate, and tartrate. Separation and Purification Technology, Vol. 62, pp. 330-336.

Kameda, T.; Yamazaki, T.; Yoshioka, T. (2008b). Preparation and characterization of Mg-Al layered double hydroxides intercalated with benzenesulfonate and benzenedisulfonate. Microporous and Mesoporous Materials, Vol. 114, pp. 410-415.

Kameda, T.; Takeuchi, H.; Yoshioka, T. (2009a). Hybrid inorganic/organic composites of $\mathrm{Mg}-\mathrm{Al}$ layered double hydroxides intercalated with citrate, malate, and tartrate prepared by co-precipitation. Materials Research Bulletin, Vol. 44, pp. 840-845.

Kameda, T.; Takeuchi, H.; Yoshioka, T. (2009b). Preparation of organic acid anion-modified magnesium hydroxides by coprecipitation: A novel material for the uptake of heavy metal ions from aqueous solutions. Journal of Physics and Chemistry of Solids, Vol. 70, pp. 1104-1108. 
Kameda, T.; Saito, M.; Umetsu, Y. (2009c). Continuous treatment of bisphenol A and diethyl phthalate solutions using dodecylsulfate-intercalated $\mathrm{Mg}-\mathrm{Al}$ layered double hydroxide particles packed in column. Materials Transactions, Vol. 50, pp. 1541-1547.

Kameda, T.; Yamazaki, T.; Yoshioka, T. (2009d). Selective uptake of aromatic compounds from aqueous solutions by $\mathrm{Mg}-\mathrm{Al}$ layered double hydroxide intercalated with 2,7naphthalene disulfonate. Chemistry Letters, Vol. 38, pp. 522-523.

Kameda, T.; Yamazaki, T.; Yoshioka, T. (2009e). Preparation of Mg-Al layered double hydroxide intercalated with 2,7-naphthalene disulfonate and its selective uptake of aromatic compounds from aqueous solutions. Bulletin of the Chemical Society of Japan, Vol. 82, pp. 1436-1440.

Kameda, T.; Tsuchiya, Y.; Yamazaki, T.; Yoshioka, T. (2009f). Preparation of Mg-Al layered double hydroxides intercalated with alkyl sulfates and investigation of their capacity to take up $\mathrm{N}, \mathrm{N}$-dimethylaniline from aqueous solutions. Solid State Sciences, Vol. 11, pp. 2060-2064.

Kameda, T.; Takeuchi, H., Yoshioka, T. (2010a). Kinetics of uptake of $\mathrm{Cu}^{2+}$ and $\mathrm{Cd}^{2+}$ by $\mathrm{Mg}-$ Al layered double hydroxides intercalated with citrate, malate, and tartrate. Colloids and Surfaces A: Physicochemical and Engineering Aspects, Vol. 355, pp. 172-177.

Kameda, T.; Yamazaki, T., Yoshioka, T. (2010b). Preparation of Mg-Al layered double hydroxides intercalated with 1,3,6-naphthalenetrisulfonate and 3-amino-2,7naphthalenedisulfonate and assessment of their selective uptake of aromatic compounds from aqueous solutions. Solid State Sciences, Vol. 12, pp. 946-951.

Kameda, T.; Yamazaki, T., Yoshioka, T. (2010c). Effect of intercalated aromatic sulfonates on uptake of aromatic compounds from aqueous solutions by modified $\mathrm{Mg}-\mathrm{Al}$ layered double hydroxide. Materials Research Bulletin, Vol. 45, pp. 751-753.

Kameda, T.; Hoshi, K.; Yoshioka, T. (2011). Uptake of Sc ${ }^{3+}$ and $\mathrm{La}^{3+}$ from aqueous solution using ethylenediaminetetraacetate-intercalated $\mathrm{Cu}-\mathrm{Al}$ layered double hydroxide reconstructed from $\mathrm{Cu}-\mathrm{Al}$ oxide. Solid State Sciences, Vol. 13, pp. 366-371.

Kang, M. J.; Rhee, S. W.; Moon, H.; Neck, V.; Fanghanel, Th. (1996). Sorption of $\mathrm{MO}_{4^{-}}(\mathrm{M}=$ $\mathrm{Tc}, \mathrm{Re})$ on $\mathrm{Mg} / \mathrm{Al}$ layered double hydroxide by anion exchange. Radiochimica Acta, Vol. 75, pp. 169-173.

Kulyukhin, S. A.; Krasavina, E. P.; Gredina, I. V.; Rumer, I. A.; Mizina, L. V. (2008). Sorption of cesium, strontium, and yttrium radionuclides from the aqueous phase on layered double hydroxides. Radiochemistry, Vol. 50, pp. 493-501.

Lazaridis, N. K.; Asouhidou, D. D. (2003). Kinetics of sorptive removal of chromium(VI) from aqueous solutions by calcined $\mathrm{Mg}-\mathrm{Al}-\mathrm{CO}_{3}$ hydrotalcite. Water Research, Vol. 37, pp. 2875-2882.

Li, F.; Wang, Y.; Yang, Q.; Evans, D. G.; Forano, C.; Duan, X. (2005). Study on adsorption of glyphosate ( $\mathrm{N}$-phosphonomethyl glycine) pesticide on MgAl-layered double hydroxides in aqueous solution. Journal of Hazardous Materials, Vol. B125, pp. 89-95.

Liang, X.; Hou, W.; Xu, Y.; Sun, G.; Wang, L.; Sun, Y.; Qin, X. (2010). Sorption of lead ion by layered double hydroxide intercalated with diethylenetriaminepentaacetic acid. Colloids and Surfaces A: Physicochemical and Engineering Aspects, Vol. 366, pp. 50-57.

Lukashin, A. V.; Vertegel, A. A.; Eliseev, A. A.; Nikiforov, M. P.; Gornert, P.; Tretyakov, Y. D. (2003). Chemical design of magnetic nanocomposites based on layered double hydroxides. Journal of Nanoparticle Research, Vol. 5, pp. 455-464. 
Meyn, M.; Beneke, K.; Lagaly, G. (1990). Anion-exchange reactions of layered double hydroxides. Inorganic Chemistry, Vol. 29, pp. 5201-5207.

Nakayama, H.; Hirami, S.; Tsuhako, M. (2007). Selective adsorption of mercury ion by mercaptocarboxylic acid intercalated $\mathrm{Mg}-\mathrm{Al}$ layered double hydroxide. Journal of Colloid and Interface Science, Vol. 315, pp. 177-183.

Narita, E.; Yamagishi, T.; Tazawa, K.; Ichijo, O.; Umetsu, Y. (1995). Uptake behavior of chelating agents by magnesium-aluminum oxide precursor with reconstruction of hydrotalcite-like layer structure. Clay Science, Vol. 9, pp. 187-197.

Newman, S. P.; Jones, W. (1998). Synthesis, characterization and applications of layered double hydroxides containing organic guests. New journal of chemistry, Vol. 22, pp. 105-115.

Ogata, S.; Tasaka, Y.; Tagaya, H.; Kadokawa, J.; Chiba, K. (1998). Preparation of new fibrous layered compounds by the reaction of zinc hydroxide with organic compounds. Chemistry Letters, Vol. 27, pp. 237-238.

Ogata, S.; Tagaya, H.; Kadokawa, J.; Chiba, K. (2000). Preparation of new fibrous organicinorganic layered compounds derived from zinc hydroxide. Molecular Crystals and Liquid Crystals, Vol. 341, pp. 419-424.

Orthman, J.; Zhu, H. Y.; Lu, G. Q. (2003). Use of anion clay hydrotalcite to remove coloured organics from aqueous solutions. Separation and Purification Technology, Vol. 31, pp. 53-59.

Pavlovic, I.; Perez, M. R.; Barriga, C.; Ulibarri, M. A. (2009). Adsorption of $\mathrm{Cu}^{2+}, \mathrm{Cd}^{2+}$ and $\mathrm{Pb}^{2+}$ ions by layered double hydroxides intercalated with the chelating agents diethylenetriaminepentaacetate and meso-2,3-dimercaptosuccinate. Applied Clay Science, Vol. 43, pp. 125-129.

Pavlovic, I.; Ulibarri, M. A.; Hermosin, M. C.; Cornejo, J. (1997). Sorption of an anionic surfactant from water by a calcined hydrotalcite-like sorbent. Fresenius Environmental Bulletin, Vol. 6, 266-271.

Pavlovic, I.; Barriga, C.; Hermosin, M. C.; Cornejo, J.; Ulibarri, M.A. (2005). Adsorption of acidic pesticides 2,4-D, Clopyralid and Picloram on calcined hydrotalcite. Applied Clay Science, Vol. 30, pp. 125-133.

Perez, M. R.; Pavlovic, I.; Barriga, C.; Cornejo, J.; Hermosin, M. C.; Ulibarri, M.A. (2006). Uptake of $\mathrm{Cu}^{2+}, \mathrm{Cd}^{2+}$ and $\mathrm{Pb}^{2+}$ on $\mathrm{Zn}-\mathrm{Al}$ layered double hydroxide intercalated with EDTA. Applied Clay Science, Vol. 32, pp. 245-251.

Rhee, S. W.; Kang, M. J.; Kim, H.; Moon, C. H. (1997). Removal of aquatic chromate ion involving rehydration reaction of calcined layered double hydroxide (Mg-Al- $\left.\mathrm{CO}_{3}\right)$. Environmental Technology, Vol. 18, pp. 231-236.

Rojas, R.; Perez, M. R.; Erro, E. M.; Ortiz, P. I.; Ulibarri, M. A.; Giacomelli, C. E. (2009). EDTA modified LDHs as $\mathrm{Cu}^{2+}$ scavengers: Removal kinetics and sorbent stability. Journal of Colloid and Interface Science, Vol. 331, pp. 425-431.

Saito, C.; Okada, H.; Titus, M. J.; Yoshioka, T.; Mizoguchi, T. (2007). Leaching of heavy metals from fly ash generated from gasification and melting furnace for municipal solid wastes by organic acids. Haikibutsu Gakkai Ronbunshi, Vol. 18, pp. 157-166.

Sato, T.; Okuyama, H.; Endo, T.; Shimada, M. (1990). Preparation and photochemical properties of cadmium sulphide-zinc sulphide incorporated into the interlayer of hydrotalcite. Reactivity of Solids, Vol. 8, pp. 63-72. 
Setti, N. D.; Jouini, N.; Derriche, Z. (2010). Sorption study of an anionic dye benzopurpurine 4B - on calcined and uncalcined $\mathrm{Mg}-\mathrm{Al}$ layered double hydroxides. Journal of Physics and Chemistry of Solids, Vol. 71, pp. 556-559.

Sun, Z.; Jin, L.; Shi, W.; Wei, M.; Duan, X. (2010). Preparation of an anion dye intercalated into layered double hydroxides and its controllable luminescence properties. Chemical Engineering Journal, Vol. 161, pp. 293-300.

Tagaya, H.; Ogata, S.; Morioka, H.; Kadokawa, J.; Chiba, K. (1996). New preparation method for surface-modified inorganic layered compounds. Journal of Materials Chemistry, Vol. 6, pp. 1235-1237.

Takahashi, S.; Iwasa, T.; Kanazawa, Y.; Umetsu, Y.; Narita, E. (1997). Formation of organic anion-pillared layered zinc hydroxides by coprecipitation. Nippon Kagaku Kaishi, Vol. 1997, pp. 502-507.

Taylor, H. F. W. (1973). Crystal structures of some double hydroxide minerals. Mineralogical Magazine, Vol. 39, pp. 377-389.

Tronto, J.; Crepaldi, E. L.; Pavan, P. C.; Paula, C. C.; Valim, J. B. (2001). Organic anions of pharmaceutical interest intercalated in magnesium aluminum LDHs by two different methods. Molecular Crystals and Liquid Crystals, Vol. 356, pp. 227-237.

Tronto, J.; Reis, M. J.; Silverio, F.; Balbo, V. R.; Marchetti, J. M.; Valim, J. B. (2004) In vitro release of citrate anions intercalated in magnesium aluminium layered double hydroxides. Journal of Physics and Chemistry of Solids, Vol. 65, pp. 475-480.

Tsuji, M.; Matsunami, J.; Tamamura, Y. (1999). Selective removal of selenium in wastewater by hydrotalcite with high layer charge. Transactions of the Materials Research Society of Japan, Vol. 24, pp. 357-360.

Tsyganok, A. I.; Suzuki, K.; Hamakawa, S.; Takehira, K.; Hayakawa, T. (2001a). Alternative approach to incorporation of nickel into layered structure of $\mathrm{Mg}-\mathrm{Al}$ double hydroxides: intercalation with [Ni(EDTA) $]^{2-}$ species. Chemistry Letters, Vol. 30, pp. 24-25.

Tsyganok, A. I.; Suzuki, K.; Hamakawa, S.; Takehira, K.; Hayakawa, T. (2001b). Mg-Al layered double hydroxide intercalated with [Ni(EDTA) $]^{2-}$ chelate as a precursor for an efficient catalyst of methane reforming with carbon dioxide. Catalysis Letters, Vol. 77, pp. 75-86.

Tsyganok, A.; Sayari, A. (2006). Incorporation of transition metals into $\mathrm{Mg}-\mathrm{Al}$ layered double hydroxides: Coprecipitation of cations vs. their pre-complexation with an anionic chelator. Journal of Solid State Chemistry, Vol. 179, pp. 1829-1840.

Ulibarri, M. A.; Pavlovic, I.; Hermosin, M. C.; Cornejo, J. (1995). Hydrotalcite-like compounds as potential sorbents of phenols from water. Applied Clay Science, Vol. 10, pp. 131-145.

Valente, J. S.; Tzompantzi, F.; Prince, J.; Cortez, J. G. H.; Gomez, R. (2009). Adsorption and photocatalytic degradation of phenol and 2,4 dichlorophenoxiacetic acid by $\mathrm{Mg}-\mathrm{Zn}$ Al layered double hydroxides. Applied Catalysis B: Environmental, Vol. 90, pp. 330338.

Villa, M. V.; Sanchez-Martin, M. J.; Sanchez-Camazano, M. (1999). Hydrotalcites and organo-hydrotalcites as sorbents for removing pesticides from water. Journal of Environmental Science \& Health, Vol. B34, pp. 509-525.

Vreysen, S.; Maes, A. (2008). Adsorption mechanism of humic and fulvic acid onto $\mathrm{Mg} / \mathrm{Al}$ layered double hydroxides. Applied Clay Science, Vol. 38, pp. 237-249. 
Wang, B.; Zhang, H.; Evans, D. G.; Duan, X. (2005). Surface modification of layered double hydroxides and incorporation of hydrophobic organic compounds. Materials Chemistry and Physics, Vol. 92, pp. 190-196.

Wang, S. L.; Liu, C. H.; Wang, M. K.; Chuang, Y. H.; Chiang, P. N. (2009). Arsenate adsorption by $\mathrm{Mg} / \mathrm{Al}-\mathrm{NO}_{3}$ layered double hydroxides with varying the $\mathrm{Mg} / \mathrm{Al}$ ratio. Applied Clay Science, Vol. 43, pp. 79-85.

Yang, L.; Shahrivari, Z.; Liu, P. K. T.; Sahimi, M.; Tsotsis, T.T. (2005). Removal of trace levels of arsenic and selenium from aqueous solutions by calcined and uncalcined layered double hydroxides (LDH). Industrial \& Engineering Chemistry Research, Vol. 44, pp. 6804-6815.

You, Y. W.; Zhao, H. T.; Vance, G. F. (2001a). Removal of arsenite from aqueous solutions by anionic clays. Environmental Technology, Vol. 22, pp. 1447-1457.

You, Y.; Vance, G. F.; Zhao, H. (2001b). Selenium adsorption on $\mathrm{Mg}-\mathrm{Al}$ and $\mathrm{Zn}-\mathrm{Al}$ layered double hydroxides. Applied Clay Science, Vol. 20, pp. 13-25.

You, Y.; Zhao, H.; Vance, G. F. (2002a). Adsorption of dicamba (3,6-dichloro-2-methoxy benzoic acid) in aqueous solution by calcined-layered double hydroxide. Applied Clay Science, Vol. 21, pp. 217-226.

You, Y.; Zhao, H.; Vance, G. F. (2002b). Surfactant-enhanced adsorption of organic compounds by layered double hydroxides. Colloids and Surfaces A: Physicochemical and Engineering Aspects, Vol. 205, pp. 161-172.

Zhang, J.; Zhang, F.; Ren, L.; Evans, D. G.; Duan, X. (2004). Synthesis of layered double hydroxide anionic clays intercalated by carboxylate anions. Materials Chemistry and Physics, Vol. 85, pp. 207-214.

Zhao, H.; Nagy, K. L. (2004). Dodecyl sulfate-hydrotalcite nanocomposites for trapping chlorinated organic pollutants in water. Journal of Colloid and Interface Science, Vol. 274, pp. 613-624. 


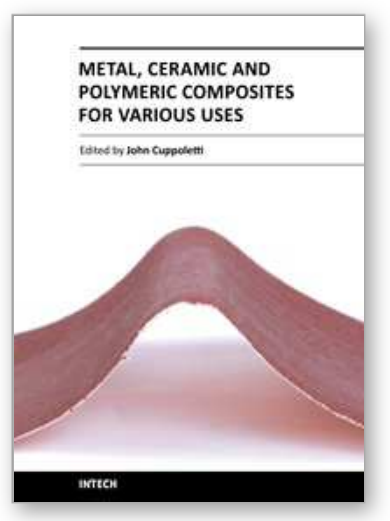

\author{
Metal, Ceramic and Polymeric Composites for Various Uses \\ Edited by Dr. John Cuppoletti
}

ISBN 978-953-307-353-8

Hard cover, 684 pages

Publisher InTech

Published online 20, July, 2011

Published in print edition July, 2011

Composite materials, often shortened to composites, are engineered or naturally occurring materials made from two or more constituent materials with significantly different physical or chemical properties which remain separate and distinct at the macroscopic or microscopic scale within the finished structure. The aim of this book is to provide comprehensive reference and text on composite materials and structures. This book will cover aspects of design, production, manufacturing, exploitation and maintenance of composite materials. The scope of the book covers scientific, technological and practical concepts concerning research, development and realization of composites.

\title{
How to reference
}

In order to correctly reference this scholarly work, feel free to copy and paste the following:

Tomohito Kameda and Toshiaki Yoshioka (2011). Hybrid Inorganic/Organic Composites of Layered Double Hydroxides Intercalated with Organic Acid Anions for the Uptake of Hazardous Substances from Aqueous Solution, Metal, Ceramic and Polymeric Composites for Various Uses, Dr. John Cuppoletti (Ed.), ISBN: 978953-307-353-8, InTech, Available from: http://www.intechopen.com/books/metal-ceramic-and-polymericcomposites-for-various-uses/hybrid-inorganic-organic-composites-of-layered-double-hydroxides-intercalatedwith-organic-acid-anio

\section{INTECH}

open science | open minds

\author{
InTech Europe \\ University Campus STeP Ri \\ Slavka Krautzeka 83/A \\ 51000 Rijeka, Croatia \\ Phone: +385 (51) 770447 \\ Fax: +385 (51) 686166 \\ www.intechopen.com
}

\author{
InTech China \\ Unit 405, Office Block, Hotel Equatorial Shanghai \\ No.65, Yan An Road (West), Shanghai, 200040, China \\ 中国上海市延安西路65号上海国际贵都大饭店办公楼 405 单元 \\ Phone: +86-21-62489820 \\ Fax: $+86-21-62489821$
}


(C) 2011 The Author(s). Licensee IntechOpen. This chapter is distributed under the terms of the Creative Commons Attribution-NonCommercialShareAlike-3.0 License, which permits use, distribution and reproduction for non-commercial purposes, provided the original is properly cited and derivative works building on this content are distributed under the same license. 